\title{
The Technology Benefits
}

of Inertial Confinement Fusion Research

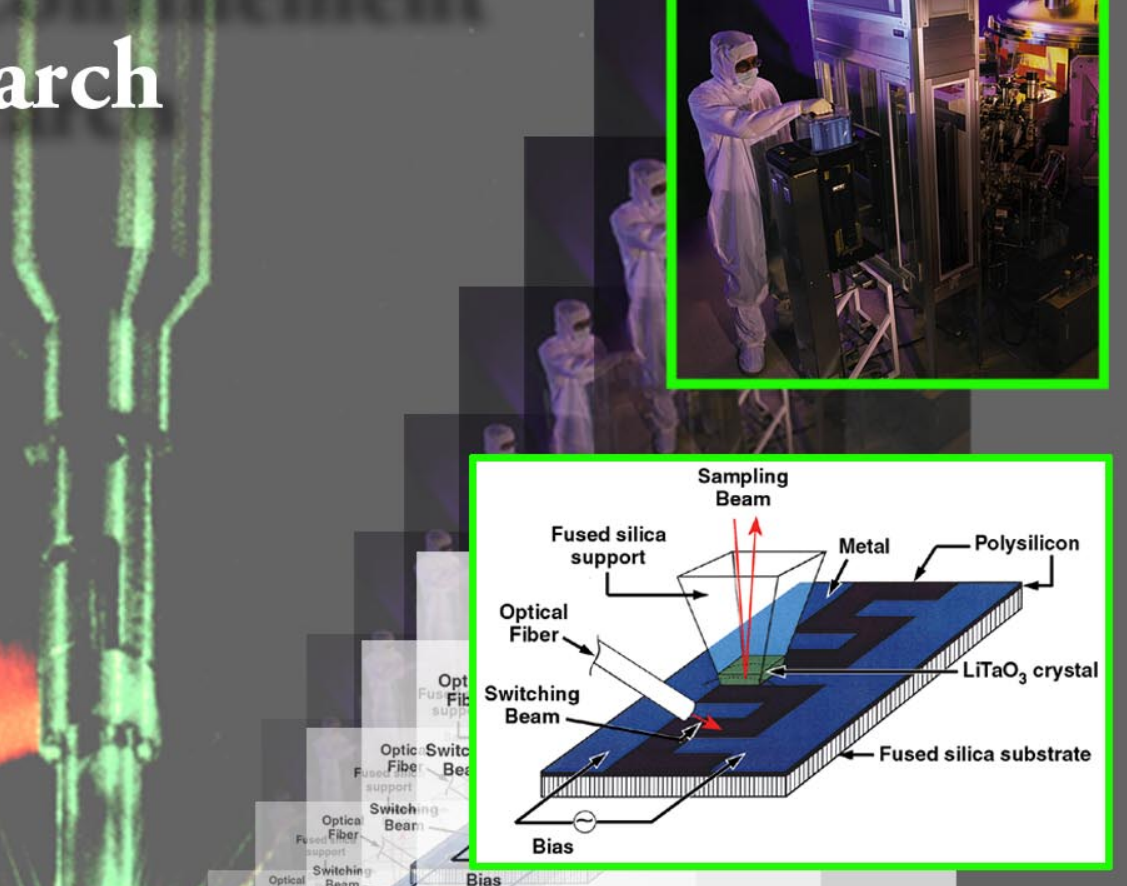


DISCLAIMER

This document was prepared as an account of work sponsored by an agency of the United States Government. Neither the United States Government nor the University of California nor any of their employees, makes any warranty, express or implied, or assumes any legal liability or responsibility for the accuracy, completeness, or usefulness of any information, apparatus, product, or process disclosed, or represents that its use would not infringe privately owned rights. Reference herein to any specific commercial products, process, or service by trade name, trademark, manufacturer, or otherwise, does not necessarily constitute or imply its endorsement, recommendation, or favoring by the United States Government or the University of California. The views and opinions of authors expressed herein do not necessarily state or reflect those of the United States Government or the University of California, and shall not be used for advertising or product endorsement purposes.

\author{
This report has been reproduced \\ directly from the best available copy. \\ Available to DOE and DOE contractors from the \\ Office of Scientific and Technical Information \\ P.O. Box 62, Oak Ridge, TN 37831

Work performed under the auspices of the U.S. Department of Energy by Lawrence Livermore National Laboratory under Contract W-7405-Eng-48.

\title{
On the cover
}

Photograph of a laser-irradiated target with overlain examples of spin-off technology.

From top to bottom: The ICF program has a long history of providing spin-offs to the semiconductor industry. The prototype system shown here will be used in extreme ultraviolet lithography development for the manufacture of semiconductor circuits; electro-optic sampling circuit used to measure subpicosecond electrical pulses; short-pulse laser removal of dental caries; and $\mathrm{H}$ igh-Speed Electromagnetic Roadway M apping and Evaluation System using micropower impulse radar in a drive over bridge inspection test. 


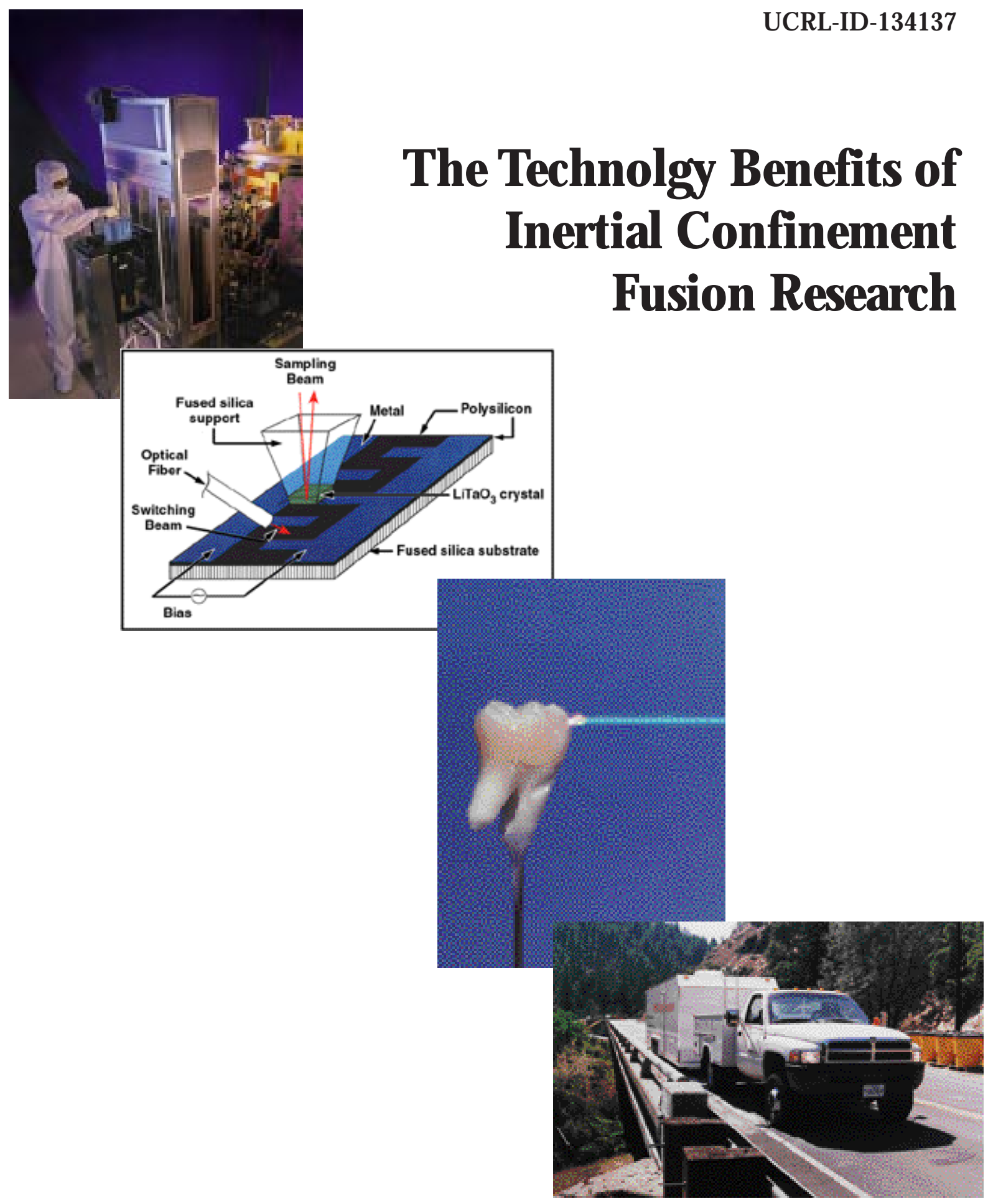

LAWREN CE LIVERMORE NATIONAL LABORATORY University of C alifornia • Livermore, C alifornia • 94550 



\section{Table of Contents}

Introduction

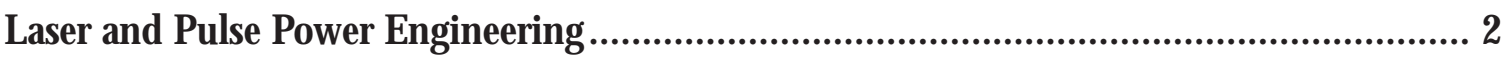

O ptics, Materials, and Manufacturing .............................................................. 8

D iagnostics and Instrumentation .................................................................... 10

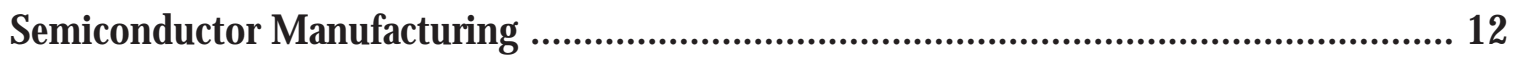

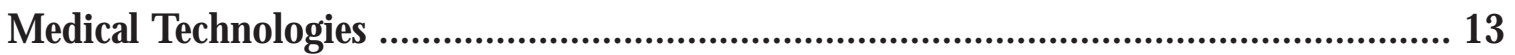

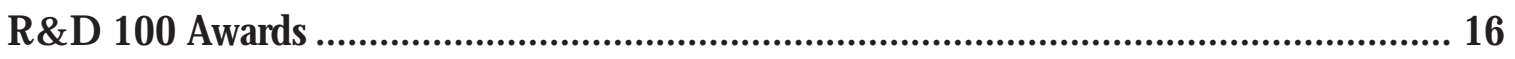

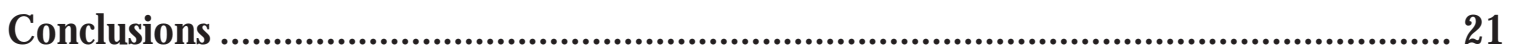



Inertial Fusion Technology Spin-0 fís- History Provides A Glimpse of the Future

\section{Introduction}

The development and demonstration of inertial fusion is incredibly challenging because it requi res simultaneously controlling and precisely measuring parameters at extreme values in energy, space, and time. The challenges range from building megajoule $\left(10^{6} \mathrm{~J}\right)$ drivers that perform with percent-level precision to fabricating targets with submicron specifications to measuring target performance at mi cron scale $\left(10^{-6} \mathrm{~m}\right)$ with picosecond $\left(10^{-12} \mathrm{~s}\right)$ time resolution. 0 ver the past 30 years in attempting to meet this challenge, the inertial fusion community around the world has invented new technologies in lasers, particle beams, pulse power drivers, diagnostics, target fabrication, and other areas. These technologi es have found applications in diverse fields of industry and science. M oreover, simply assembling the teams with the background, experience, and personal drive to meet the challenging requirements of inertial fusion has led to spin-offs in unexpected directions, for example, in laser isotope separation, extreme ultraviolet lithography for microelectronics, compact and inexpensive radars, advanced laser materials processing, and medical technology. The experience of inertial fusion research and development of spinning off technologies has not been unique to any one laboratory or country but has been similar in main research centers in the U nited States, Europe, and Japan.

Strengthening and broadening the inertial fusi on effort to focus on creating a new source of electrical power (inertial fusion energy [IFE]) that is economically competitive and environmentally benign will yield rich rewards in technology spin-offs. The additional challenges presented by IFE are to make drivers affordable, efficient, and long-lived while operating at a repetition rate of a few Hertz; to make fusion targets that perform consistently at high-fusion yield; and to create target chambers that can repetitvely handle greater than $100-\mathrm{M} \mathrm{J}$ yields while producing minimal radioactive by-products. M eeting these 
challenges will produce spin-off value of enormous magnitude. By exploring the technology spin-offs of the inertial fusion community to date, we can glimpse the expected future rewards from an IFE program.

The information in this document has been collected from inertial fusion colleagues around the world, including various individuals at the University of Rochester-Laboratory of Laser Energetics (LLE), Lawrence Livermore $N$ ational Laboratory (LLNL), 0 saka U niversity - Institute of Laser Engineering (ILE), Rutherford Appleton Laboratory-Central Laser Facility (CLF), Sandia $N$ ational Laboratories (SN L), Lawrence Berkeley $N$ ational Laboratory (LBN L), and Los Alamos $\mathrm{N}$ ational Laboratory (LAN L).

The technological spin-offs are divided into the following categories: laser and pulsed power engineering; optics, materials, and manufacturing; diagnostics and instrumentation; semiconductor manufacturing; and medical technology. Laser and pulse power engineering spin-offs flow directly from inertial fusion driver developments. $M$ aterials and materials processing spin-offs have naturally occurred because improved materials are fundamentally enabling for inertial fusion as well as for many other fields. Including optics in this group recognizes the fact that optical materials and manufacturing are increasingly becoming enabling technologies of the $21^{\text {st }}$ century. Spinoffs in diagnostics and instrumentation largely derive from the challenging measurement of target phenomenon. Spin-offs in semi-conductor and medical technology have arisen from numerous areas and simply from the creativity and breadth of view of individuals working in target and driver technology.

O ne measure of industrial spin-off value in the United States is the R\&D 100 Awards, which some have called the "O scars of applied research." $M$ embers of the inertial fusion community have been highly succesful in winning these awards presented for the most technologically significant products each year. A table at the end of the document describes more than $40 R \& D \quad 100$ Awards that have been received by members of this community over the past 30 years. Another measure of spin-off value, and arguably the most important, are companies that were founded or were greatly enhanced based on inertial fusion technology developments as described throughout this paper.

\section{Laser and Pulse Power Engineering}

Since the early 1970 s the primary lasers used for inertial fusion research have been based on flashlamp-pumped $\mathrm{N}$ d:glass. M egajoule-class fusion ignition facilities based on this technology are now under construction in Livermore, CA (N ational I gnition Facility) and in Bordeaux, France (Laser M egaloule). Laser design improvements and simulations to increase the output energy, power, precision, beam quality, and flexibility of solid-state lasers has been a focus of the inertial fusion laser community for many years. The community has made fundamental contributions to the laser field with improvements in the laser-damage threshold of optics, spatial filtering and optical relaying to minimize beam modulation, methods for nonlinear frequency conversion to produce ultraviolet laser beams, diffractive optics to sample and manipulate beams on target, and beam smoothing to reduce laser speckle in a time integrated sense. The fusion community has driven the physics understanding of high-power laser beam propagation, which has had applications in fields ranging from military lasers to fiber-based telecommunications.

Gas lasers, particularly KrF excimer lasers, have also been used for inertial fusion research. KrF, which operates directly at $0.25 \mu \mathrm{m}$ in the ultraviolet, has had the advantage of easily producing a broad-bandwidth, smooth beam on target as developed at the $\mathrm{N}$ aval Research Laboratory for inertial fusion research. High-energy versions of this laser require improvements in pulse power technology, discussed below, as well as in the damage threshold of ultraviolet optics, which have 
broad applications. It is notable that the direct output of smaller-scale KrF lasers based on discharges (manufactured by Cymer Lasers in the U nited States) are currently being used in state-ofthe-art semiconductor lithography via shortwavelength, high-resolution imaging of masks.

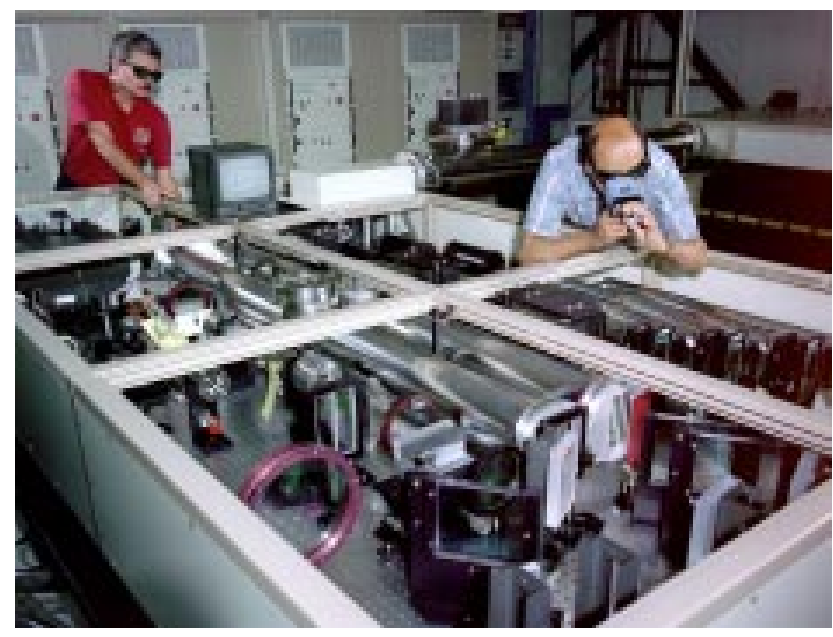

A zig-zag slab Nd:glass laser producing $60-\mathrm{J}$ green output at $<2 x$ diffraction limited at $3 \mathrm{~Hz}$ for Advanced Imaging Testbed experiments. This technology is also used for laser peening.

Two major solid-state laser design innovations coming directly from or greatly enhanced by inertial fusion laboratories have been zig-zag and short-pulse lasers based on chirped pulse amplification (CPA) lasers. T he parentage and early development of zig-zag and CPA lasers have been strongly connected with both LLE's and LLN L's inertial fusion programs.

Solid-state zig-zag lasers, invented at G eneral Electric Corporation, are designed to increase the average power of solid-state lasers by using thin slabs of gain media rather than rods to provide effective cooling while providing large beam area to produce high-output power. They utilize a totally internally-reflecting zig-zag beam path to average out phase distortions to produce a high quality beam. Both LLN L's and LLE's laser teams have devel oped zig-zag lasers for kilowatt-class industry and military applications (x-ray lithography and laser peening are discussed below). The LLN L group added the important feature of stimulated Brillouin scattering phase conjugation to produce diffraction-limited high-power beams. The former director of LLE and several staff formed $\mathrm{H}$ ampshire Instruments, which attempted to develop an industrial tool for contact x-ray lithography of microcircuits by specifically applying phase-conjugated zig-zag laser technology to produce $x$-rays. The use of laser-produced plasmas to produce keV $\mathrm{x}$-rays capable of producing extremely fine feature sizes was itself an invention coming directly from LLE in 1983. LLN L's laser program has recently delivered a multibeam laser based on flashlamp-pumped zig-zag laser technology that is being used by the Air Force Research Laboratory for advanced imaging of satellites. Interestingly, zig-zag laser technology is now spinning back into the inertial fusion field where such lasers are finding application at LLN L for damage testing of $\mathrm{N}$ ational I gnition Facility (N IF) optics and at ILE in Japan where they are being pursued as a possible high-power laser drivers for inertial fusion energy based on laser diode pumping.

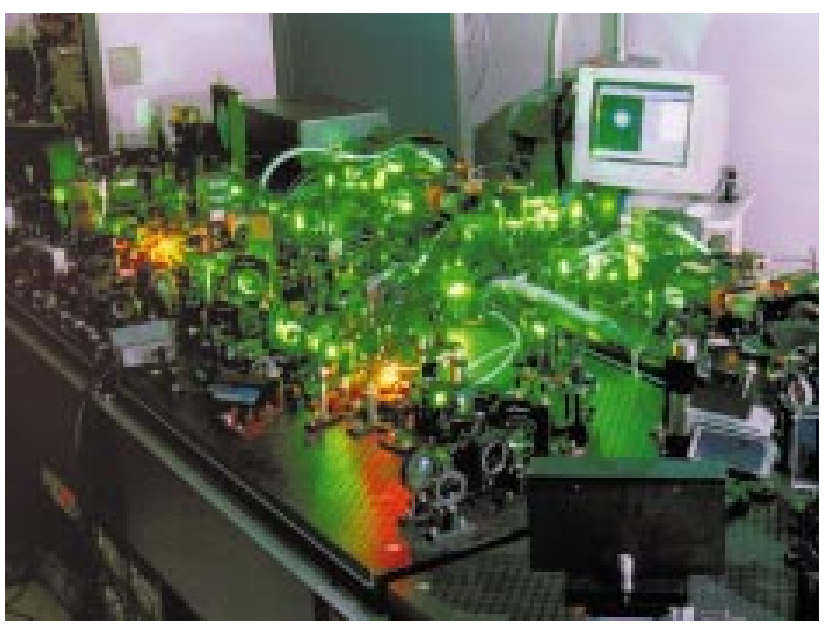

A 15-W CPA laser developed for laser cutting, employed at the Y-12 plant.

The technique of CPA, originally used for the generation of intense microwaves pulses, was first developed for solid-state lasers by LLN L in the early 70 s and by M ourou and coworkers at LLE in 1985. It is now used in nearly all high-power ultra-short pulse lasers and has revolutionized the ultrafast science field. The general concept is first to stretch a short pulse in time by dispersing its frequency components, to amplify this muchlonger "chirped" pulse to high power avoiding undesired nonlinear effects, and finally to recompress the pulse in time at the output using a pair of gratings. The CPA technique has allowed "tabletop terawatt $\left(\mathrm{T}^{3}\right)^{3}$ " laser systems that produce relevant power densities for inertial fusion research 
without investing in large laser systems. The largest-scale application of CPA technology was the demonstration of a Petawatt laser by Perry and colleagues at LLN L in 1996 for applications ranging from making $\mathrm{M}$ eV $\mathrm{x}$ rays for dense object radiography to researching new approaches to inertial fusion. By using the broadband laser material, $\mathrm{Ti}$ :sapphire, relatively simple femtosecond lasers can be used to create and probe ultrashort events with femtosecond resolution for diverse scientific applications. A recent application of a high-power Ti:sapphire CPA technology is the generation of deuterium-deuterium fusion neutrons on a tabletop by $D$ itmire and coworkers at LLN L. To satisfy the scientific user community, high-power CPA lasers are now being sold by several companies in the United States and Europe (Positive Light, Clark, and Thompson). Several efforts are underway to increase the average power of CPA lasers specifically for femtosecond materials processing as discussed in the next section.

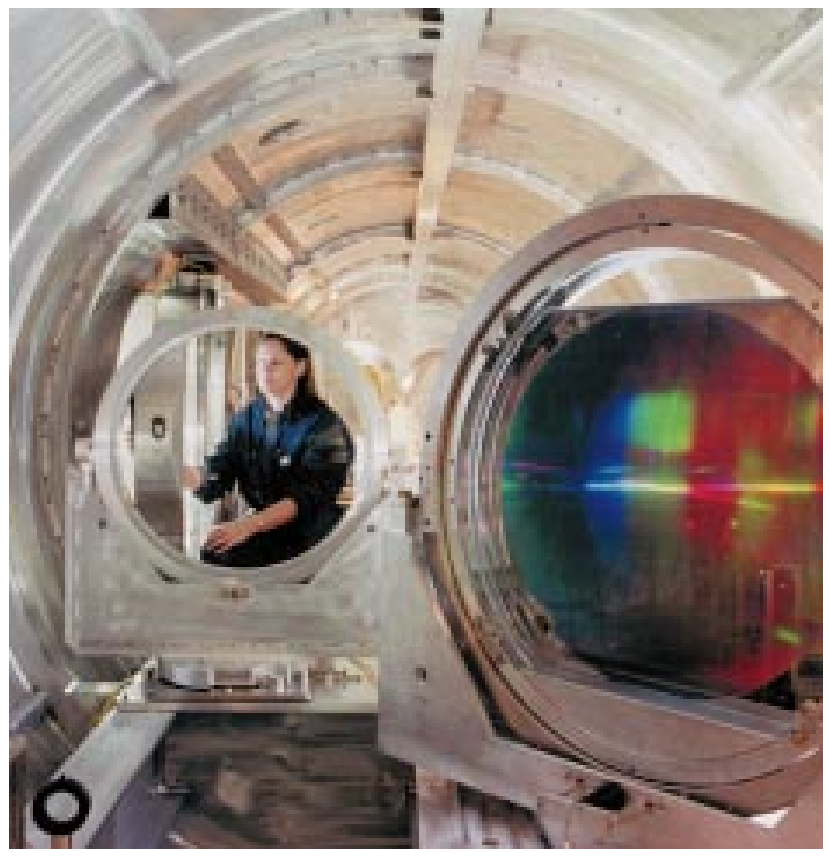

Scientist inside the Petawatt vacuum compression chamber at LLNL, which is used to compress a nanosecnd-duration spectrally chirped pulse to less than one picosecond in duration. This temporal compression is performed by a pair of meter-scale gratings, one of which is seen on the right. The development of chirped-pulse-amplification laser technology has led to several industrially important spin-offs.
Recently the solid-state laser driver community for inertial fusion has been turning toward diodepumped solid-state lasers (D PSSLs) as the preferred technology choice of the future. D PSSLs offer compactness, efficiency, and long life at the expense of using high-power semiconductor laser diodes. The present price of laser diodes limits the scale of the systems in which they can be practically used. N onetheless, the regenerative amplifiers of the N IF, which provide the preponderance of beamline gain (from nanojoules up to millijoules), utilize this technology. D PSSLs are a spin-back into inertial fusion from $D$ epartment of $D$ efense (DoD) and commercial developments, which have their roots in inertial fusion in the 1980s. For example, the N IF utilizes lens ducts for delivering laser diode power, which were invented at $L L N L$ originally for non-ICF uses and later commercialized by VLOC, a division of IIVI Corporation. Similarly in Japan, the inertial fusion effort at ILE has developed laser diodes and microlens delivery systems for welding, cutting, and drilling that have been transferred to $\mathrm{N}$ alux Corp. and $\mathrm{H}$ amamatsu Photonics. $\mathrm{H}$ amamatsu and ILE are now working closely together on the development of D PSSLs as eventual drivers for fusion energy.

The large-scale applications that will drive the price of high-power laser diodes into a commodity market have yet to be established. Such industrial applications, when they occur, will similarly be of high spin-off value as well as be enabling for D PSSL $s$ as fusion energy drivers. It is worthwhile noting that diode lasers are a backbone component of the 1.5- $\mu \mathrm{m}$ wavelength fiber telecommunication industry in which they are currently more than a \$1 billion dollar annual market. D PSSLs are currently used for materials processing lasers operating at kilowatt power levels being marketed by TRW in the U nited States and Rofin Sinar in Germany. Similar D PSSL systems are now in development at M itsubishi, Toshiba, and several other companies in Japan. H owever, the first very large-scale application of high-power D PSSL s is likely to be for military use. LLN L, 
under U .S. Army support, is now beginning development of D PSSL s for point defense against tactical missiles. DPSSL development for defense against strategic missile attack is now being actively discussed by the Air Force and others. It is relevant that the $\$ 1.2$ billion Airborne Laser now under construction for the Air Force utilizes D PSSLs for illuminating and tracking missiles, which are then engaged by more highly developed chemical gas lasers.
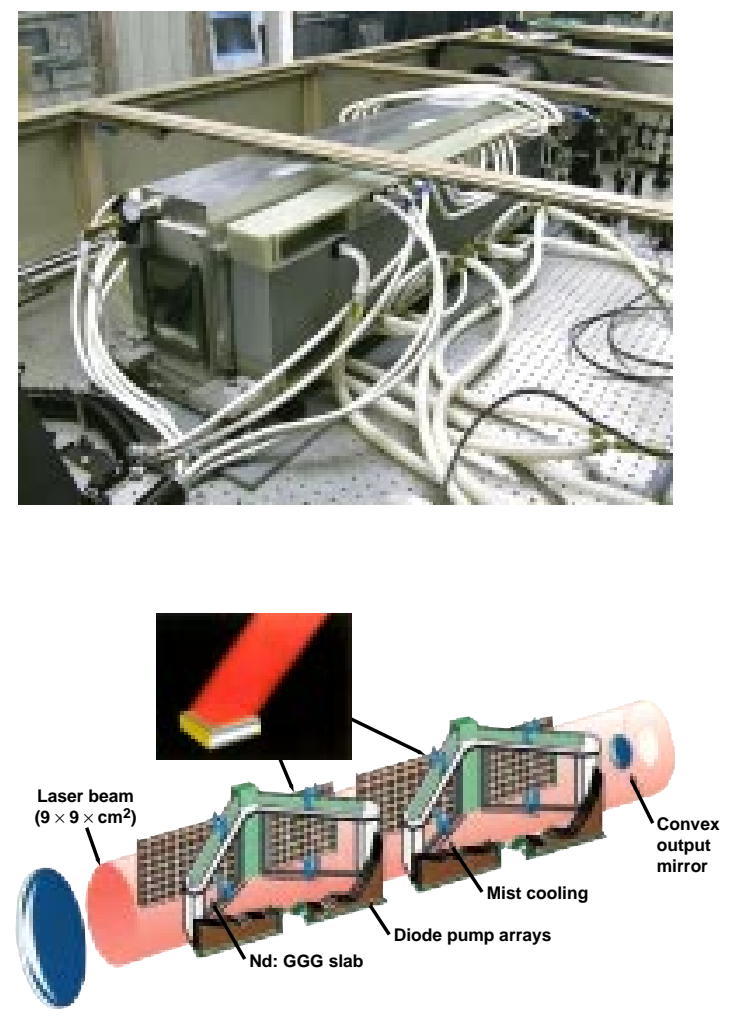

A heat capacity laser testbed using flashlamps as a surrogate pump source was operated to investigate beam quality limits. The schematic shows the configuration of a 100-kW diode-pumped prototype being developed for the Army's High Energy Laser Strategic Test Facility.

The development of pulse power drivers for inertial fusion has had an equally strong effect within its broad community. The development of pulsed power capability for inertial fusion applies to the D OD where hardening military electronics against the radiation produced by nuclear blasts has been a major concern. This technology also applies to $\mathrm{N}$ ational Aeronautics and Space Administration and the space community where hardening of space probes and satellites against solar and cosmic radiation is also a strong concern. Broadening beyond their ICF developments, SN L has developed Repetitively Pulsed High-Energy Pulse Power (RHEPP) systems in which large timeintegrated $x$-ray doses can be generated. RH EPP technology has been applied to food sterilization, demilitarization, decontamination of chemical and biological weapons, elastomer processing, and for adding enthalpy to simulate hypersonic flow in wind tunnels. Q uantum M anufacturing Technologies, Alameda Applied Sciences, and M egapulse, Inc. have all benefitted directly from SN L's work. This technology is now spinning back into the inertial fusion community where the $\mathrm{N}$ aval Research Laboratory ( $\mathrm{NL}$ ) is applying the RH EPP developments to the Electra electronbeam-pumped KrF laser now under development specifically for application to IFE.

As in the laser community, small, compact pulse power sources have also been developed having industrial applications such as x-ray sources for microelectronics lithography and generating ion beams that provide surface treatment of metals and ceramics.

The pulse power codes developed at Sandia within the inertial fusion program have found various industrial applications. The code Q UICKSILVER has been used for commercial microelectronics packaging design of high-speed network chip packages and for cell phone memory interconnects. It is currently licensed to the $C$ entre D 'Etudes, Gramat (CEG), France; N RL; and the Universities of Arizona and Illinois. The codes SCREAM ER and ATH ETA have been licensed commercially for the design of repetitive pulse power accelerators to Q uantum $M$ anufacturing, $N R L, C E G$, and several other corporations. The three-dimensional hydro code ALEGRA is now being used for shock physics and structural response calculations for high-stress radiation environments and high-velocity impact environments (such as satellites encountering space debris). 
Lawrence Berkeley N ational Laboratory (LBN L) has devel oped induction accelerators over the past twenty years, and specifically over the past several years for heavy-ion accel erators for IFE. The LBN L heavy-ion fusion (HIF) effort has recently been integrated with LLN L's Beam R esearch Group. Their induction accelerator developments have had application within the defense community, for example at the $\mathrm{D}$ ual Axis $\mathrm{H}$ ydro Test Facility (D ARH T) now under construction at LoS Alamos, where a pair of electron induction linacs are used to generate intense $x$ rays, which in turn are used to image the implosion process created by conventional explosives. Also, solid-state modulator technology originally designed for H IF recirculators has been applied to the design of the proposed Advanced Radiography $M$ achine, which requires a similarly high repetition rate (to image the implosion at several points in time). This work has also benefited the high-energy physics and light-source communities through the development of injectors for relativisitic klystrons, improving our understanding of space charge physics, and developments for high-power free electron lasers. The use of induction accelerators for food sterilization has also been investigated. The H IF group has also been prolific in generating codes such as WARP and GYM NOS, which have applied to the modeling of space-chargedominated beams with applications in highenergy physics, atomic vapor laser isotope separation, and plasma processing. An accelerator for Boron N eutron Capture Therapy for medical treatment uses an injector modeled after heavyion fusion developments. See the table below for further examples of heavy-ion fusion and pulsed power spin-off technologies coming from $L B N L$ and SN L.

\section{Spin-offs and C ross D isciplinary C onnections to Pulsed Power and H eavy Ion Fusion}

\begin{tabular}{|c|c|c|}
\hline Categories & $\begin{array}{l}\text { ICF/IFE } \\
\text { Technology Spin- } \\
\text { off }\end{array}$ & Where and How Used \\
\hline $\begin{array}{l}\text { Induction } \\
\text { accelerators }\end{array}$ & $\begin{array}{l}\text { Dual Axis Hydro } \\
\text { Test Facility } \\
\text { (DAHRT) }\end{array}$ & $\begin{array}{l}\text { For stockpile stewardship (injector, linac, and final focus areas benefited from HIF } \\
\text { staff and experience) }\end{array}$ \\
\hline $\begin{array}{l}\text { Induction } \\
\text { accelerators }\end{array}$ & $\begin{array}{l}\text { Advanced } \\
\text { Radiography } \\
\text { Machine }\end{array}$ & $\begin{array}{l}\text { (Proposed) for stockpile stewardship. (High repetition- rate flexible format FET } \\
\text { pulse modulators originally developed for HIF recirculator) }\end{array}$ \\
\hline $\begin{array}{l}\text { Induction } \\
\text { accelerators }\end{array}$ & $\begin{array}{l}\text { Injector for } \\
\text { Relativistic } \\
\text { Klystrons }\end{array}$ & For high energy physics research \\
\hline $\begin{array}{l}\text { Induction } \\
\text { accelerators }\end{array}$ & $\begin{array}{l}\text { University of } \\
\text { Maryland Electron } \\
\text { Ring (UMER) }\end{array}$ & $\begin{array}{l}\text { At U. Md. for studies of space-charge physics (highly influenced by HIF } \\
\text { recirculator design) }\end{array}$ \\
\hline $\begin{array}{l}\text { Induction } \\
\text { accelerators }\end{array}$ & $\begin{array}{l}\text { High-power free- } \\
\text { electron lasers }\end{array}$ & $\begin{array}{l}\text { common beam research personnel involved in both FEL and HIF research (both } \\
\text { with high peak power, low-emittance beam requirements) }\end{array}$ \\
\hline $\begin{array}{l}\text { Induction } \\
\text { accelerators }\end{array}$ & $\begin{array}{l}\text { Composite curing } \\
\text { using induction } \\
\text { linac }\end{array}$ & $\begin{array}{l}\text { material fabrication of polymer composites using electron beams. Science } \\
\text { Research Laboratory outgrowth of Beam Research program }\end{array}$ \\
\hline $\begin{array}{l}\text { Induction } \\
\text { accelerators }\end{array}$ & $\begin{array}{l}\text { Other potential } \\
\text { applications }\end{array}$ & $\begin{array}{l}\text { Spallation neutron source for materials research, tritium production, waste } \\
\text { transmutation, subcritical nuclear power generation, and/or fusion materials } \\
\text { research }\end{array}$ \\
\hline $\begin{array}{l}\text { Computer } \\
\text { Software }\end{array}$ & $\begin{array}{l}\text { Space-charge } \\
\text { dominated beam } \\
\text { codes }\end{array}$ & $\begin{array}{l}\text { WARP-used for many accelerators (AVLIS (laser isotope separation) electron beam } \\
\text { injector (GSI bunch compression in rings, UMER (electron ring experiments) } \\
\text { GYMNOS used in DARHT simulations and plasma processing applications }\end{array}$ \\
\hline $\begin{array}{l}\text { Computer } \\
\text { Software }\end{array}$ & $\begin{array}{l}\text { Interactive User } \\
\text { Interface }\end{array}$ & $\begin{array}{l}\text { The linkage of Fortran to the scripting language Python, developed for the HIF } \\
\text { code WARP, is being used by the MFE code UEDGE, and likely other tools soon }\end{array}$ \\
\hline
\end{tabular}




\begin{tabular}{|c|c|c|}
\hline Categories & $\begin{array}{l}\text { ICF/IFE } \\
\text { Technology Spin- } \\
\text { off }\end{array}$ & Where and How Used \\
\hline Beam Transport & $\begin{array}{l}\text { Transport of space- } \\
\text { charge dominated } \\
\text { beams }\end{array}$ & $\begin{array}{l}\text { Demonstrated first in HIF theory and later in HIF experiments. Now applicable to } \\
\text { many LINAC injectors; Applied directly to design of the Fermilab Tevatron main } \\
\text { injector upgrade }\end{array}$ \\
\hline Beam Transport & $\begin{array}{l}\text { Space charge } \\
\text { effects in bends }\end{array}$ & LEP curvature aberration effects deduced by HIF theorists \\
\hline Beam Transport & $\begin{array}{l}\text { Space-charge and } \\
\text { neutralization } \\
\text { effects }\end{array}$ & $\begin{array}{l}\text { Imitron, medical accelerator design aided by knowledge of neutralization physics } \\
\text { deduced by HIF theory }\end{array}$ \\
\hline Beam Transport & $\begin{array}{l}\text { Theory of beam } \\
\text { modes and beam } \\
\text { stability }\end{array}$ & $\begin{array}{l}\text { Longitudinal instability, temperature anisotropy instability, kinetic and fluid beam } \\
\text { modes }\end{array}$ \\
\hline Beam Transport & $\begin{array}{l}\text { Theory of beam } \\
\text { halo }\end{array}$ & $\begin{array}{l}\text { HIF theorists have contributed to longitudinal halo theory applied to high average } \\
\text { power accelerators such as APT and NSNS }\end{array}$ \\
\hline $\begin{array}{l}\text { General } \\
\text { Accelerator }\end{array}$ & $\begin{array}{l}\text { Medical } \\
\text { accelerators }\end{array}$ & $\begin{array}{l}\text { Accelerator for Boron Neutron Capture Therapy (BNCT) - medical accelerator } \\
\text { (injector modeled after HIF ESQ injector) }\end{array}$ \\
\hline $\begin{array}{l}\text { General } \\
\text { Accelerator }\end{array}$ & Beam cooling & $\begin{array}{l}\text { Electron cooling at Fermilab (HIF scientists contributed to beam dynamics studies } \\
\text { of low-emittance and space-charge dominated beams) }\end{array}$ \\
\hline $\begin{array}{l}\text { General } \\
\text { Accelerator }\end{array}$ & Plasma lens & $\begin{array}{l}\text { Plasma lens for high energy physics (SLAC, LBNL) and high energy density } \\
\text { physics (GSI) }\end{array}$ \\
\hline $\begin{array}{l}\text { Accelerator } \\
\text { Components }\end{array}$ & $\begin{array}{l}\text { Long pulse } \\
\text { induction cores }\end{array}$ & $\begin{array}{l}\text { Pioneered the use of Allied Signal Metglas amorphous iron tape for long pulse } \\
\text { length, low power loss induction cores }\end{array}$ \\
\hline $\begin{array}{l}\text { Accelerator } \\
\text { Components }\end{array}$ & $\begin{array}{l}\text { Superconducting } \\
\text { magnet arrays }\end{array}$ & $\begin{array}{l}\text { Extension of superconducting magnet technology to low aspect ratio, multiple } \\
\text { beam arrays, which may have applications to other high power accelerator } \\
\text { applications }\end{array}$ \\
\hline $\begin{array}{l}\text { Pulsed power } \\
\text { components }\end{array}$ & $\begin{array}{l}\text { Radiation Effects } \\
\text { Testing }\end{array}$ & $\begin{array}{l}\text { The short pulse technology developed for the ICF program has been used to build } \\
\text { pulsed-power accelerators that drive z-pinch loads for soft x-ray radiation effects } \\
\text { testing }\end{array}$ \\
\hline $\begin{array}{l}\text { Pulsed power } \\
\text { components }\end{array}$ & $\begin{array}{l}\text { Repetitive Pulsed } \\
\text { Power }\end{array}$ & $\begin{array}{l}\text { High average power repetitive pulsed power systems have been developed to drive } \\
\text { many loads, ranging from soft x-ray to electron beam to ion beam diodes }\end{array}$ \\
\hline $\begin{array}{l}\text { Pulsed power } \\
\text { components }\end{array}$ & $\begin{array}{l}\text { Low power } \\
\text { repetitive ion } \\
\text { diodes }\end{array}$ & $\begin{array}{l}\text { Low power ion beams have been developed for several industrial applications, } \\
\text { including surface treatment of metals and ceramics }\end{array}$ \\
\hline $\begin{array}{l}\text { Pulsed power } \\
\text { components }\end{array}$ & $\begin{array}{l}\text { Repetitive electron } \\
\text { beam diodes }\end{array}$ & $\begin{array}{l}\text { Repetitive electron beam diodes have been developed for several industrial } \\
\text { applications, including electron beam welding, as a source of high energy x-rays } \\
\text { for use in food sterilization, for demilitarization and decontamination of chemical } \\
\text { and biological weapons, for elastomer processing, and for adding enthalpy to } \\
\text { simulate hypersonic flow in windtunnels }\end{array}$ \\
\hline $\begin{array}{l}\text { Pulsed power } \\
\text { components }\end{array}$ & $\begin{array}{l}\text { Repetitive soft } x- \\
\text { ray sources }\end{array}$ & $\begin{array}{l}\text { Low power repetitive soft } x \text {-ray sources have been developed for such applications } \\
\text { as x-ray microlithography }\end{array}$ \\
\hline $\begin{array}{l}\text { Pulsed power } \\
\text { components }\end{array}$ & $\begin{array}{l}\text { Radiation- } \\
\text { hardening }\end{array}$ & $\begin{array}{l}\text { Diagnostics and electronics used in pulsed power must be protected from the harsh } \\
\text { environment that is present. The methods of protection have applications to the } \\
\text { space industry. }\end{array}$ \\
\hline $\begin{array}{l}\text { Pulsed power } \\
\text { diagnostics }\end{array}$ & Radiography & $\begin{array}{l}\text { Inductive Voltage Accelerators are used to generate high-current, small-spot-size, } \\
\text { intense bremsstrahlung source for use as backlighters of large samples }\end{array}$ \\
\hline
\end{tabular}




\section{Optics, Materials, and Manufacturing}

Improving laser damage has been an important area of inertial fusion driver research that has had broad applications within the laser community. For example, multilayer coating techniques based on the research conducted with the inertial fusion programs at LLNL and LLE in the U nited States and at ILE in Japan for increasing optical laser damage resistance and monitoring the fabrication of of multilayer reflectors and polarizer coatings have appeared in the product lines of both U.S. companies (Spectra Physics and O CLI) and Japanese companies (Showa O ptronics). The phosphate laser glass utilized in the N IF and Laser $M$ egal oule was originally developed by LLE working with $\mathrm{H}$ oya $\mathrm{C}$ orp. and later refined to eliminate damaging platinum particle inclusions by LLN L working in concert with both Schott G lass Technology and H oya. LLN L also worked with Schott G lass Technology to develop highstrength phophate laser glass (APG -1 and APG -2) for high-average-power laser applications. LLE, working with $\mathrm{K}$ igre Corp. and $\mathrm{GE} /$ Binghamton, N.Y., demonstrated the first surface strengthening of phosphate glass, again specifically for highaverage-power laser operation.

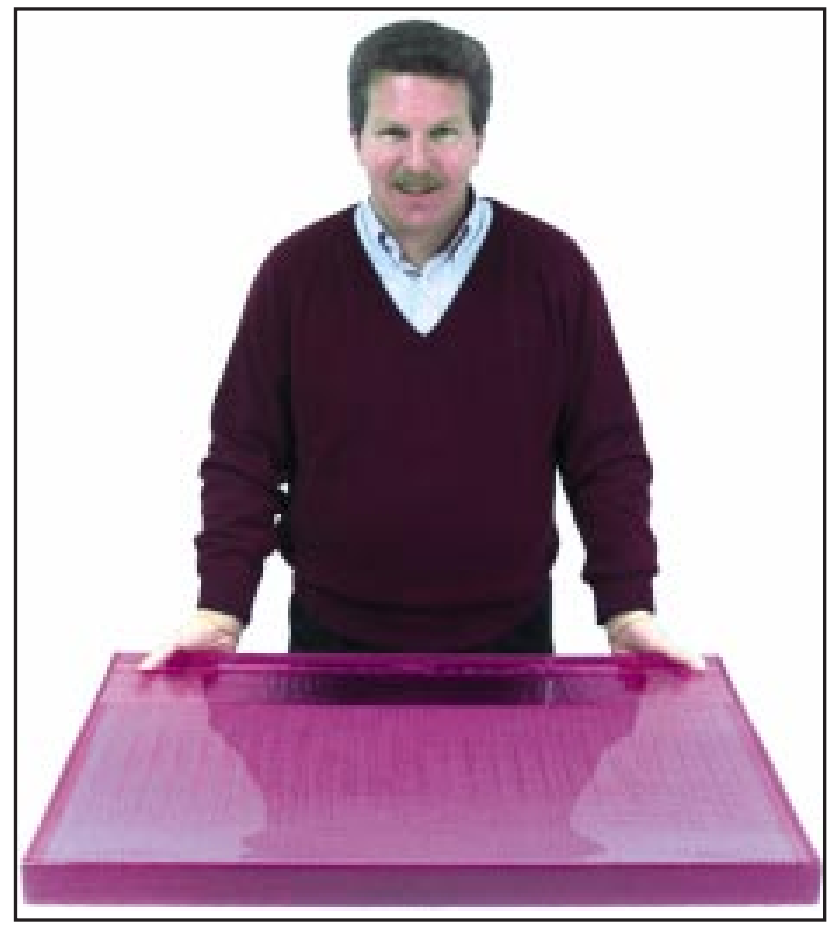

NIF Large-aperture phosphate laser glass blank as cut from a continuously melted glass strip.
The growth of crystals for laser media and for nonlinear conversion has been a valuable concentration of the ICF community. LLN L invented the broadband lamp-pumped laser material, $\mathrm{Cr}$ :LiSAF, and transferred the technology to VLOC, a division of II-VI Corp. Following its original exploration in Russia, LLN L has perfected the rapid growth of KDP conversion crystals and transferred that technology to Cleveland Crystals Inc. and Inrad in the U nited States, and through the French Commissariat a L'Energie Atomique, to Crismatek in France. This new crystal growth method will make possible producing the large quantity of near-perfect crystals needed for both the N IF and Laser M egal oule.

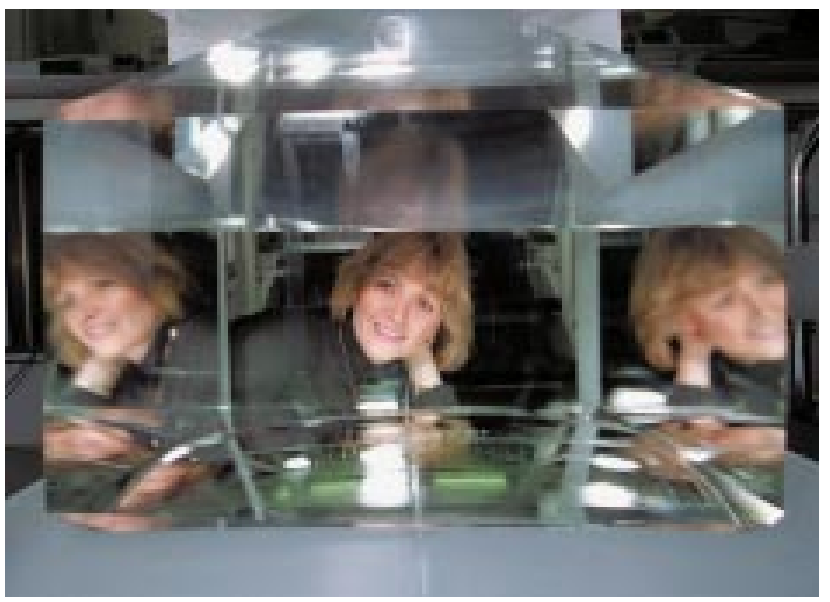

Potassium dihydrogen phosphate (KDP) crystal created with rapid-growth method.

Fabrication of optical components has been another area in which ICF has made important contributions to industry. The aspheric lens polishing methods developed at Tinsley for the $\mathrm{N}$ ova laser contributed to the fabrication of the corrector employed in the H ubble Space Telescope. Rapid deterministic polishing methods are now being developed for the N IF at Zygo Corp., Kodak, and Tinsley. The most advanced polishing method under investigation is magnetorheological finishing in which an externally applied magnetic field is used to control the local material removal rate by over four orders of magnitude. This process, developed at LLE in collaboration with Byelcorp Scientific Inc. with government support, is the basis of the company QED Technology, Inc., founded in Rochester, N.Y. To date, QED 
has sold seven such optical finishing machines to industry. Improvements to the polishing of ultrasmooth surfaces was also invented at LLE and is used by $\mathrm{N}$ orton, Inc. in their polishing products.

D iffractive optics consist of surface structures of order of a wavelength in depth on large optics for accomplishing specific functions. The ICF community has been a leader in the fabrication of such optics, which are used extensively in current ICF systems and will be part of the megajoule systems under construction. Both LLE and LLN L have developed special methods for controllably etching desired patterns into fused silica such as gratings and phase plates. Industrial companies in the diffractive optics field such as Rochester Photonics and Digital O ptics are appraised of the ICF work although no formal technology transfer has yet occurred.

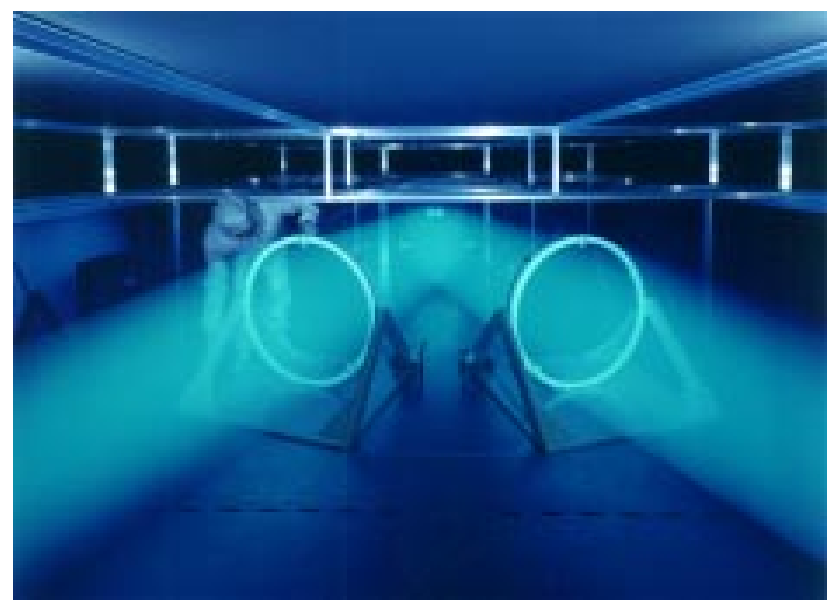

LLNL scientist inside the large-aperture diffractive optics production chamber, where the meter-scale diffraction gratings (used for compressing nanosecond spectrally chirped pulse to femtosecond duration) are produced.

C olleagues at ILE in Japan report that laser ablative shaping technology originally developed for controlling ICF beam shapes on target is being used in the development of single-mode fiber connectors by Sumitomo Electric Industries specifically to produce reasonably priced connectors for use in Fiber to the $\mathrm{H}$ ome high bandwidth telecommunications.

LLE has been a pioneer in the development of liquid crystal optical components for laser sys- tems. In 1989, LLE received an R\& D 100 award for their development of a liquid crystal polarizers used in the 0 mega laser. This technology was transferred to M eadowlark O ptics of Longmont, CO . LLE researchers found the relationship between molecular structure and laser damage in liquid crystals, which has been a key for identifying appropriate materials for high-power laser use. $M$ ore than 300 liquid crystal components have now been incorporated into the upgraded 0 mega laser for polarization control since 1995. Under support from Reveo, Inc., LLE also developed a pigment from polymer liquid crystal flakes, which produces printed patterns that are sensitive to the color and polarization of the illuminating light. Applications are envisioned in personnel security, anticounterfeiting, and printing of 3D pictures.

$M$ aterials processing with high-power lasers has been an important industrial area for some time. As mentioned previously, D PSSLs are being developed for cutting and welding in the $U$ nited States, Japan, and Europe based on research conducted in the ICF community. The application of short-pulse CPA lasers for materials processing is believed by some to be an industrial break-through, a major component of the femtosecond revolution. ICF laser development work at LLN L led to the realization that pulse lengths shorter than 1-10 ps remove material so rapidly that there is effectively no heat transfer to the remaining material. This so-called "cold cutting" is being applied to the dissassembly of nuclear weapons within the D epartment of $D$ efense's (D O E's) D efense Programs in a manner that will allow their reuse. It is also being explored for producing precision holes in aircraft engine turbine blades, for fuel injectors in diesel engines, and for tissue ablation for medical applications. Another application is laser peening in which a light pulse of $\sim 20$ ns operating an $\sim 100$ $\mathrm{J} / \mathrm{cm}^{2}$ produces shock compression to harden the surface of critical components, such as turbine blades, gears, and medical implants. Using zig-zag slab laser technology mentioned earlier, LLN L is working with M etal Improvement Corp. to commercialize this technology. 
Pulsed power component developments by the ICF community have been similarly enabling for industry. $\mathrm{H}$ igh-energy storage density capacitors based on metalized dielectrics have been developed for the NIF at Aerovox and M axwell in the United States and by three companies in Europe, while very high-current switches have been developed at Physics International. In Japan, high-average-power thyratron switches at $\mathrm{N}$ isshin Electric Company and minaturized high-energydensity capacitors at $M$ atsushita have derived from ICF researchers. For future heavy-ion fusion drivers, developments are underway for low-loss amorphous magnetic cores, castable lower-cost large insulators, cheaper regulated pulsers with solid-state switching, and robotically wound lowcost superconducting quadrapoles lenses.

Finally, the fabrication of ICF targets is worth noting as a unique manufacturing technology having niche applications. G eneral Atomic is leading the U.S. ICF program in this regard, although it depends heavily of developments originating mainly from LLN L, LAN L, and LLE. $H$ ighly spherical, extremely smooth capsules to contain the deuterium-tritium fuel are needed, with ablators that range from polymers doped with various elements for diagnostics purposes to ultra-smooth layers of beryllium. The interior hydrogen fuel is contained both in a smooth inner layer and in the residual gas that eventually provides a fusion sparkplug. The ICF community has developed high strength polyimide shells to contain the fuel, as well as thin metal permeation layers to control permeability of hydrogen. D eveloping the cryogenic systems to deploy such targets on the 0 mega laser and eventually the N IF has extended the cryogenic field for example in tritium compatible valves being developed at $\mathrm{O}$ ntario $\mathrm{H}$ ydro, which work at cryogenic temperatures. Interferometric techniques to measure the internal surface roughness have also been developed at LLE and LLN L. In England, the need to produce ICF targets with specific smallscal e features at the Central Laser Facility led to the creation of Exitech, a company who now has wide business area.

\section{Diagnostics and Instrumentation}

The ultra-high speed diagnostics used for measuring inertial fusion implosions have found application in many other fields. Streak cameras which can measure light or $\mathrm{x}$-rays with picosecond time resolution have been developed largely because of the needs of inertial fusion. The company Kentech was founded in England specifically for meeting the needs of the inertial fusion programs at Rutherford Laboratory, Imperial College, and elsewhere around the world. Kentech now specializes in high-speed electronics for a variety of applications and users. The inertial fusion programs at LLN L and LLE have also been active in developing high-dynamic-range high-speed streak cameras as well as framing cameras which can even capture $x$-ray images with a temporal resolution of a few tens of picoseconds. To handle the very large information-content images generated by inertial fusion experiments, the company O xford Framestore Applications was al so founded in England.

LAN L has been active in developing ultrasound methods to characterize ICF targets. Their noncontact diagnostic techniques, developed in part with Lasson Technology, will find application in corrosive or volatile environments and potentially at cryogenic temperatures.

M icropower impulse radar (M IR) is a LLN L spinoff invention from laser fusion diagnostics work in transient digitizers, itself an $R \& D 100$ winner in 1993. Since the first award, M IR has been applied to numerous uses, ranging from an electronic dipstick to measure fluid levels in automobiles (winning another R\&D 100 Award in 1996) to a land-mine detection system.

Based on emitting and detecting very low-amplitude voltage impulses, M IR has a sensitive detection window for accurate ranging that can be varied over time to provide radar return information at various ranges. The hardware package is very small (hand-held), made of inexpensive electronics, and has extremely low power requirements. Average emissions are well below $10 \mathrm{mV}$ and are spread over several gigahertz bandwidth, virtually eliminating unwanted reception. 


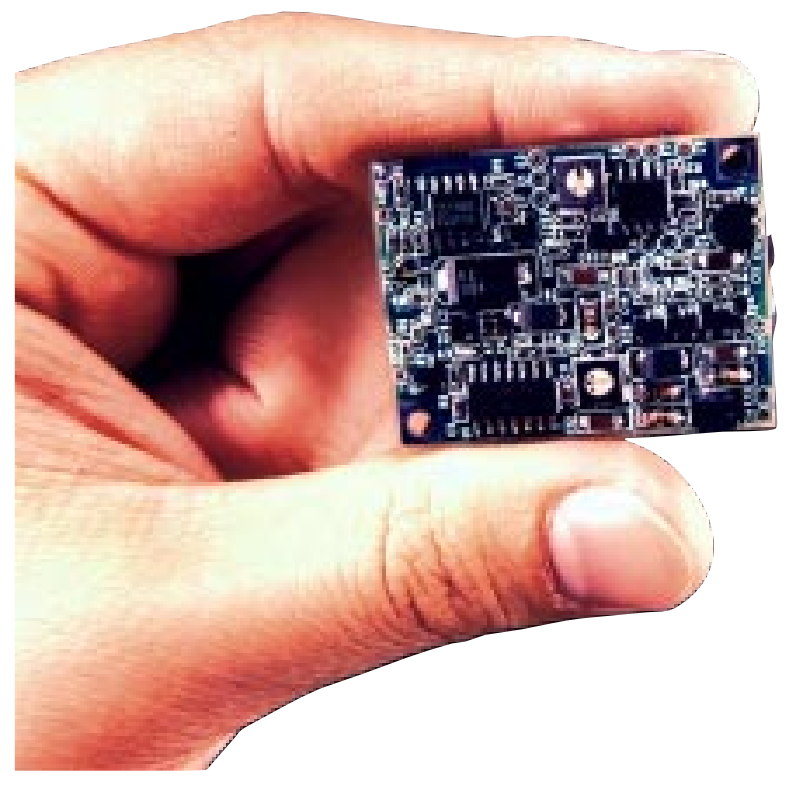

Photo of a complete MIR motion sensor system (minus antennas and standard 9-volt battery).

The M IR technology has over 30 associated patents. It has also won numerous awards and is licensed to over 20 companies. Several M IR products are now on the market.

Experiments using M IR to image concrete slabs showed vast improvements over the higherpowered, lower-frequency systems tested earlier. At the same time, Laboratory engineers were developing unique three-dimensional reconstructive imaging software, using diffraction tomography that was refined to "see" through layers of material. A system for inspecting bridges for cracks called H ERM ES is shown on the cover.

In contrast to conventional radar, which uses continuous microwave energy to detect objects over many miles, impulse radar transmits ultrashort electromagnetic pulses that allow the detection of objects at very short ranges. The M IR's pulses, producing a wide band of frequencies, generate a great deal of information about detected objects at high resolution and accuracy. The echoes of these pulses are measured by an extremely sensitive receiver that is set for a detection range of a few centimeters to many tens of meters. M IR system components also include timing circuitry, a signal processor, and antennas.
Together, they determine system range, directionality, and how well materials such as concrete, wood and other non-metallic materials can be penetrated.

An M IR system is compact and lightweight and has low power requirements; it is less expensive to produce than a conventional radar system and is amenable to many more applications. Furthermore, M IR modules can be grouped into arrays to increase system speed and area of coverage.

As described in the recent popular press (e.g., Technology Access Report, M ay 1999), the U.S. Patent and Trademark $O$ ffice is reexamining one M IR patent (per LLN L's request) against a 1987 patent from an inventor at an Alabama company. The final office action is expected in the near term.

Another important ICF diagnostic spin-off is the electrooptic sampling system developed at LLE for measuring repetitive voltage pulses in electronic circuits with subpicosecond time resolution and microvolt sensitivity. In this device a femtosecond laser is used to trigger a high speed electrical sampling switch. M ore recently LLE has developed fast photodetectors and switches based on illuminating superconductors with optical pulses. In collaboratorion with H ypress Inc., LLE has shown the first detection of single flux quantum logic pulses (1 mV-ps) based on a Josephson logic circuit.

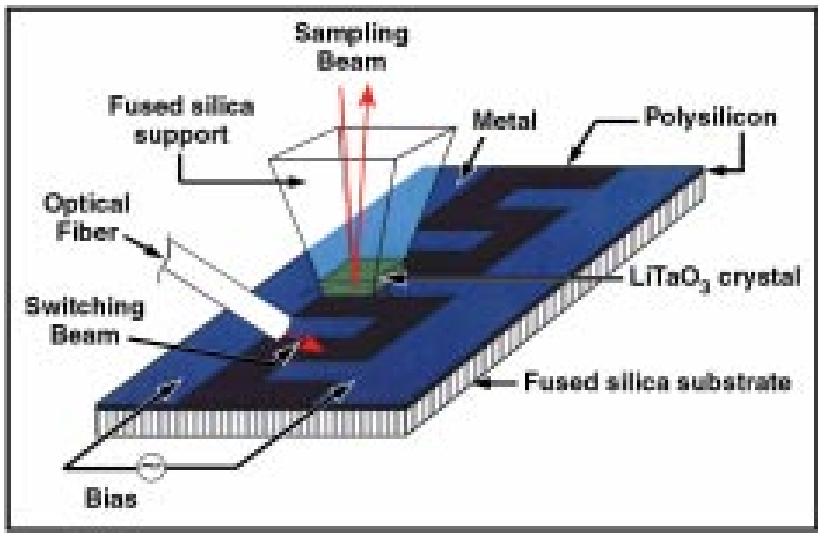

Electro-optic sampling circuit used to measure subpicosecond electrical pulses (courtesy of LLE). 


\section{Semiconductor Manufacturing}

The inertial fusion program has a long history of providing spin-offs to the semiconductor manufacturing. Attempts to develop proximity print lithography at $\mathrm{H}$ ampshire Instruments, an LLE spin-off, were mentioned earlier. Inertial fusion work at ILE in Japan has benefited the Japanese semiconductor industry such as the development of laser interferometry for the precision positioning of optical steppers employed by Canon Inc.

Extreme ultraviolet lithography (EUVL) is a new technology being developed by a consortium of three Bay Area national laboratories: Lawrence Livermore, Sandia-California, and Lawrence Berkeley. Work at these laboratories is funded by a consortium of Intel, M otorola, and Advanced $M$ icro D evices under a three year, $\$ 250 \mathrm{M}$ CRAD A agreement. M uch of the technology for optical systems at EUVL wavelengths grew out of work on diagnostics for ICF. The EUVL project will directly impact the semiconductor manufacturing industry that is approaching $\$ 200 \mathrm{~B} / \mathrm{yr}$. The U nited States accounts for half of the total semiconductor sales while Japan, Europe, and Asia account for the remainder. There are also EUVL programs in Europe and Japan, which are new and growing quickly.

M icroelectronic circuits are built-up layer-by-layer with very intricate patterns. The patterns today have details of about 250 nanometers in lateral dimension. The process of putting images of the circuit patterns on the silicon chips is called lithography. The vitality and robust growth of the semiconductor industry dictates that they follow a roadmap to make the circuit features smaller. Therefore, they need to continually develop more sophisticated lithographic processes. The resolution of images as limited by diffraction of light is directly related to the wavelength. EUVL is a method of lithography that uses very short wavelength light, about 13 nanometers, which can make very high-resolution images and, therefore, very high-resolution microelectronic circuits. In fact, the 13-nanometer light can make images with 25-nanometer features, a capability that will support the microelectronics industry until at least 2015.

The problem has been that no one has ever made a short-wavelength lithographic system with the performance and precision necessary for EUVL. The laboratories, however, have developed new types of interferometry, required to make the precision optical elements, that has an absolute accuracy many times that of prior techniques. They have developed optical coatings that reflect 10-nanometer light; these coatings are far more uniform than ever before. They have assembled an imaging camera that has surface accuracy well beyond that used in the H ubble Space Telescope which has been used to produce images with 50 nanometer circuit features. They have built diode-pumped solid state laser-produced plasma sources to generate light for the camera. These laboratory contributions are being transferred directly into the commercial sector to allow commercialization of EUVL technology.

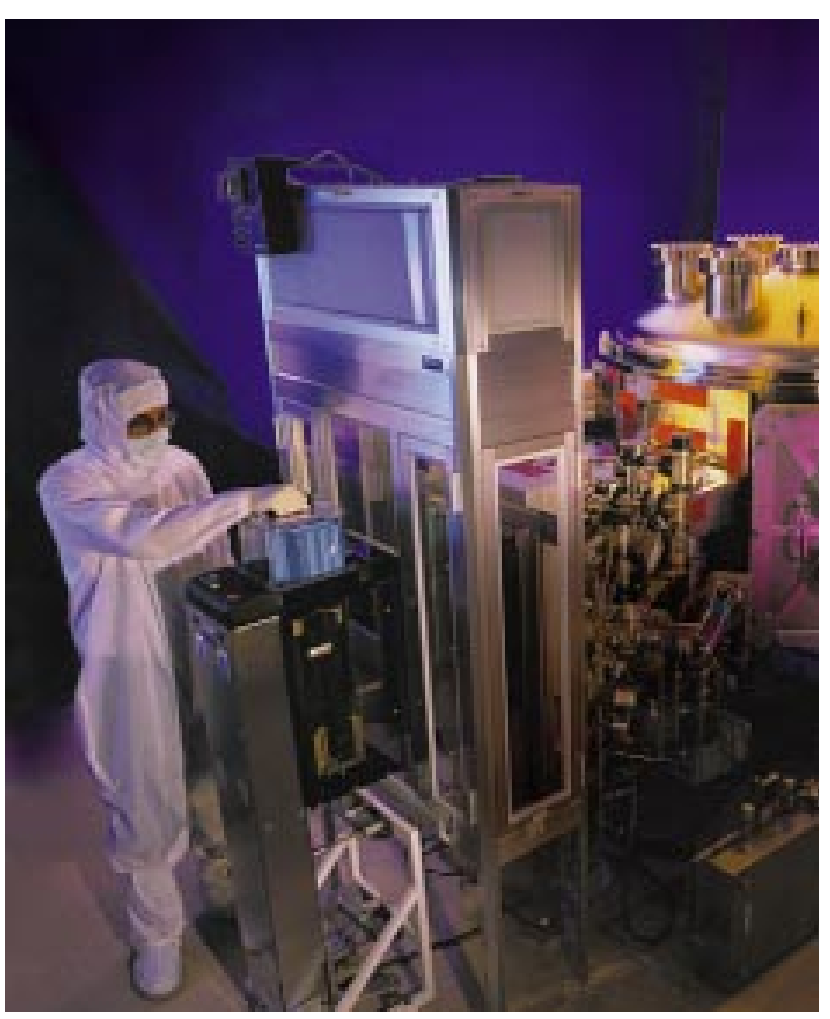

Ultra Clean Ion-Beam Sputter Deposition System that will be used in EUVL development to deposit thin films in integrated circuits 
In D ecember, 1998 an international panel of experts assembled by Sematech selected EUVL as the technology of choice for the mass production of integrated circuits for the next decade.

Some of the most important technology developments for EUVL are discussed below. It takes little imagination to see how these developments could also spin-back into filling future technology needs of inertial fusion energy.

\section{EUV 0 ptics and System}

The application of 11- to 13-nm EUV light to lithography tools that print critical dimensions in the 30- to 100-nm range requires high-precision reflective optics. These optics are used in the condenser to collect the EUV radiation from the source and to focus the radiation onto the reflective reticle in the camera to reproduce an image of the mask pattern onto the wafer. Each of the mirrors must be manufactured and assembled in the lithography subsystem to maximize the imaging efficiency and reduce distortion.

\section{EUVL M asks}

EUVL uses a reflective mask, and reflectivity at EUV wavelengths is obtained by coating a mask substrate with multilayers. The challenges include detection of sparse submicron defects on large fields. The identification and minimization of defects which can cause optical damage is of similar importance for inertial fusion.

\section{EUVL Thin Films/C oatings}

The multilayer coatings for EUV lithography systems typically consist of al ternating layers of molybdenum and silicon (M o/Si) or molybdenum and beryllium (M o/Be). The primary materialsdependent characteristics of EUV multilayer mirrors are reflectance, stress, and stability. U sing an a thermal buffer-layer technique with amorphous silicon and $\mathrm{M}$ o/Be buffer-layers, it has been possible to obtain $\mathrm{M}$ o/Be and $\mathrm{M}$ o/Si multilayers with a near-zero net film stress and less than a $1 \%$ loss in reflectance. D isposition technology challenges include thickness control and repeatability.

\section{M etrology at Near-atomic D imensions}

$\mathrm{H}$ igh-accuracy metrology tools are prerequisites for fabricating the precision optics for EUVL. I mprovements in figure metrology have been made that will enable the absolute measurement of surfaces to the accuracy required.

\section{Medical Technologies}

In 1994, researchers at LLN L began applying ICF technology and expertise developed over decades of ICF work to a new area - medical technologies. The goal was to apply ICF research and expertise to solve specific medical problems. The expertise of ICF senior scientists in lasers, optics, plasma and $\mathrm{x}$-ray diagnostics and computational models was matched with physician-identified medical needs to form a roadmap for development of key medical devices. The initial focus was treatment of stroke. Five years later several of these stroke treatment systems are being commercialized by the medical industry, and two are in early stage human trials.

The tie between ICF development and medical technologies is partially a direct adaptation of ICF technologies, but even more so, it is the use of ICF-driven expertise that can be readily applied to developing medical solutions. Below is a table of medical technologies that are being developed, or have been commercialized, using ICF-derived expertise and technology. In addition, three key technologies are featured in more detail.

\begin{tabular}{|l|l|l|}
\hline ICF Core competencies & ICF core technologies & Medical applications \\
\hline Plasma diagnostics & X-ray sources & X-ray catheter for prevention of restenosis \\
\hline Plasma Diagnostics & X-ray Characterization & $\begin{array}{l}\text { System for clinician dose measurement } \\
\text { during angiography }\end{array}$ \\
\hline Optical Florescence & Chemical sensors & Continuous glucose monitor for diabetics \\
\hline
\end{tabular}




\begin{tabular}{|c|c|c|}
\hline ICF Core competencies & ICF core technologies & Medical applications \\
\hline $\begin{array}{l}\text { Laser/matter interaction } \\
\text { modeling }\end{array}$ & LASNEX code & $\begin{array}{l}\text { Characterization of treatment system for } \\
\text { Benign Prostate Hyperplasia }\end{array}$ \\
\hline $\begin{array}{l}\text { Laser/matter interaction } \\
\text { modeling } \\
\text { Lasers and Optics }\end{array}$ & $\begin{array}{l}\text { LASNEX code } \\
\text { Diode-pumped lasers and fiber } \\
\text { optic delivery }\end{array}$ & $\begin{array}{l}\text { Opto-acoustic laser system for blood clot } \\
\text { emulsification during stroke }\end{array}$ \\
\hline Optical Design & $\begin{array}{l}\text { optical systems for ultra-short } \\
\text { pulse lasers }\end{array}$ & $\begin{array}{l}\text { Two photon photodynamic therapy for eye } \\
\text { disease }\end{array}$ \\
\hline $\begin{array}{l}\text { Precision plasma temperature } \\
\text { measurements }\end{array}$ & $\begin{array}{l}\text { Interferometric temperature and } \\
\text { shock measurements }\end{array}$ & $\begin{array}{l}\text { Measurement of laser tweezer heating for } \\
\text { in vitro fertilization }\end{array}$ \\
\hline Advanced laser systems & Optical parametric oscillators & Tissue characterization from UV to mid-IR \\
\hline $\begin{array}{l}\text { Precision temperature } \\
\text { measurement }\end{array}$ & Optical pyrometry & $\begin{array}{l}\text { Temperature measurement and feedback } \\
\text { system for Tissue Welding }\end{array}$ \\
\hline Advanced optical systems & Optical Coherence Tomography & OCT system for dental imaging \\
\hline Advanced Laser systems & Ultra short Pulse Lasers & USPL surgery system \\
\hline Plasma diagnostics & Laser-based plasma diagnostics & $\begin{array}{l}\text { USPL plasma luminescence system for } \\
\text { discriminating between bone and soft } \\
\text { tissue }\end{array}$ \\
\hline Radiation transport modeling & $\begin{array}{l}\text { Monte Carlo codes for radiation } \\
\text { transport }\end{array}$ & $\begin{array}{l}\text { Peregrine radiation treatment planning } \\
\text { system }\end{array}$ \\
\hline Complex Optical systems & Optics and spectroscopy systems & Cancer detection with an optical biopsy \\
\hline Optical Diagnostics & Optical Instrumentation & Ultra fast Spectrometer \\
\hline Laser optical systems & Specialized laser systems & $\begin{array}{l}\text { Laser Tweezers for manipulating single } \\
\text { cells }\end{array}$ \\
\hline
\end{tabular}

\section{O pto-acoustic thrombolysis \\ stroke treatment system}

Stroke is the third leading cause of death $(155,000 /$ year $)$ and the leading cause of disability in the U nited States, costing over $\$ 40$ billion/year for treatment and rehabilitation. ICF-derived research at LLN L has lead to a unique technology to aid in the disruption of stroke-causing thrombus occlusions (blood clots). This minimally invasive technique involves guiding a catheter to the site of the occlusion and introducing an optical fiber delivery system into the catheter. Laser light is coupled into the optical fiber and delivered to the occlusion, causing mechanical disruption of the occlusion and reestablishing blood flow to the brain. The light creates a vapor bubble and an acoustic wave, which is transmitted into the clot aiding in the emulsification of the clot.

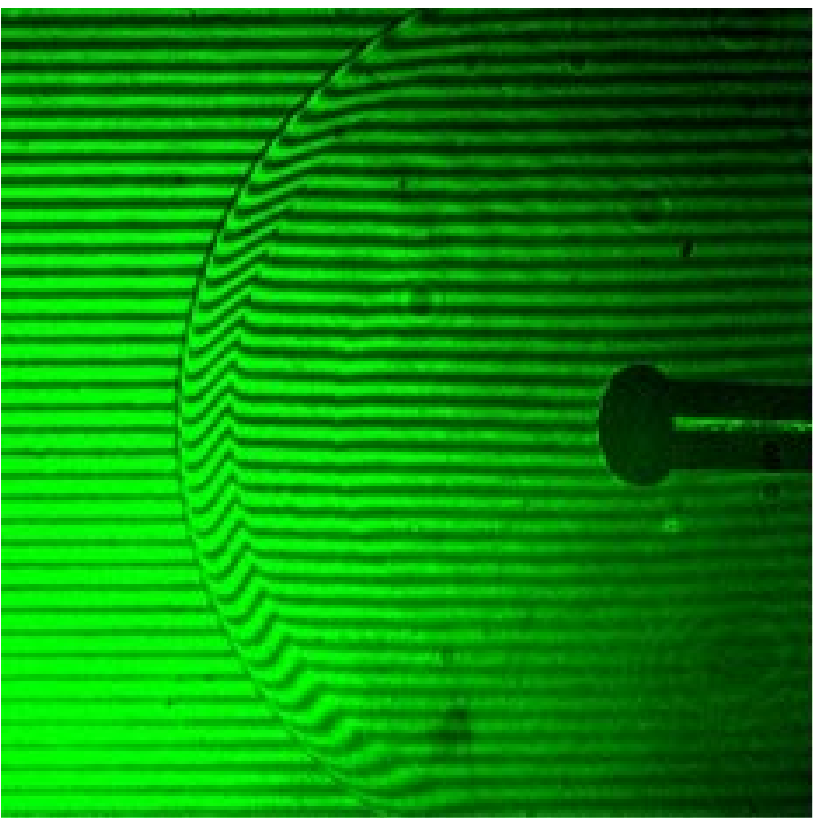

The stress wave and vapor bubble created by the deposition of laser energy through an optical fiber. 
Initial development of the laser and delivery system was performed at $L L N L$, incorporating computer modeling and experimentation, a derivative of laser and optical technologies developed within ICF. Additionally, laser-tissue interaction models, originally developed as laser-matter simulations for ICF, were crucial in optimizing the laser parameters for optimal acoustic wave effectiveness, optimizing irradiation parameters, and predicting thrombus-material failure modes. The technology was licensed to EndoVasix, Inc., which began human trails in 1998.

\section{H eart D isease Treatment with the X-R ay Catheter} $H$ eart disease caused by blockage of a coronary artery is a common medical problem, affecting over 1,000,000 Americans annually. LLN L, in conjunction with Interventional International Corporation, has developed an x-ray catheter system to address a key element of heart disease treatment. Following balloon angioplasty to reopen occluded cardiac arteries, scar tissue often forms in the artery during the natural healing process, blocking blood flow. Known as restenosis, this clogging requires repeated surgery. Research has shown that treatment of the arterial wall with ionizing radiation immediately after angioplasty can prevent restenosis. The x-ray catheter is a safe, cost-effective means of delivering this ionizing radiation in the form of $x$-rays. The technical basis for the $x$-ray catheter originated in the $x$-ray diagnostics research that has been an

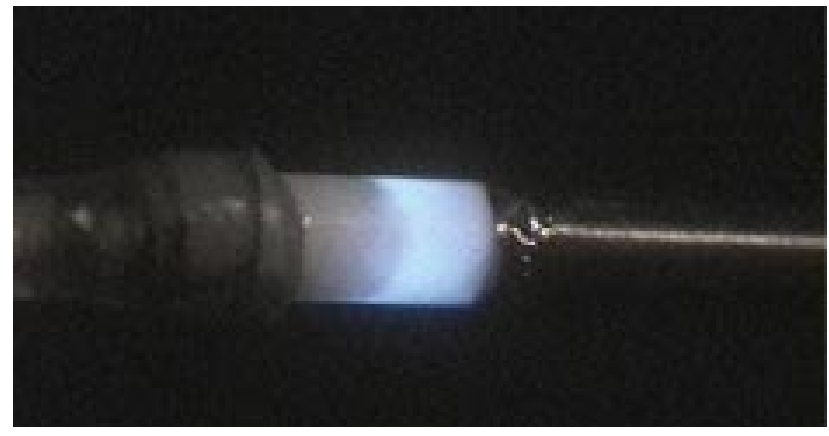

LLNL's $x$-ray catheter prototype, emitting a therapeutic $x$-ray dose (>6gy/minute). ongoing, fundamental part of the overall ICF effort. This technical excellence in $x$-ray diagnostics includes both diagnostics and sources.

\section{The U Itra-Short Pulse Laser Surgical System}

Researchers at LLN L have developed a surgical system that is an outgrowth from ICF research into ultra-short pulse lasers and the Petawatt laser for ICF experiments. The system uses an ultrashort pulse laser to create high-precision cuts without damaging surrounding tissue. The laser produces such short duration bursts of laser energy that ablation occurs without collateral damage to surrounding tissues. Combining miniaturized commercial sources of ultra-short pulse lasers with newly developed delivery systems and diagnostics have created a powerful new surgical tool that creates tiny cuts with amazingly small kerf ( $<100 \mathrm{um})$. It can also drill tiny holes ( $<150$ um diameter) all without thermal or mechanical damage to surrounding areas.

The application of this technology for corneal sculpting is under investigation at the University of M ichigan and at the company Intralase. Another area for medical applications of ultra-short pulse lasers is dentistry. A big advantage for dentistry is the minimized energy transfer from the beam to the material that is being drilled. The minimized heat transfer by the laser means the heating of the tooth, which causes patient discomfort, does not occur.

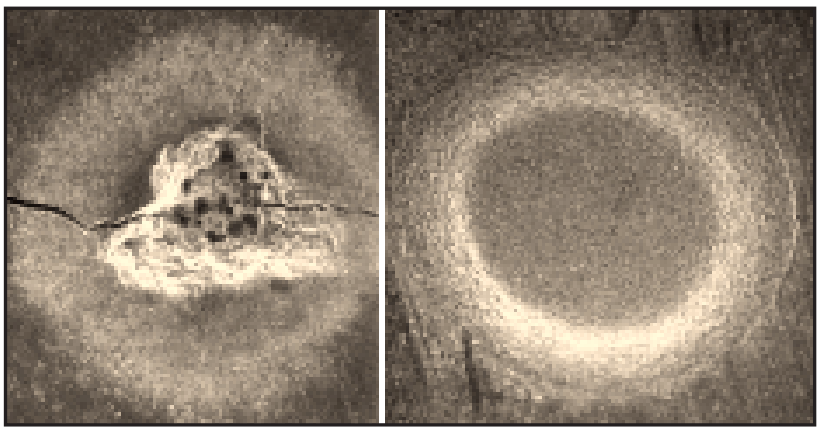

(Left) Extensive thermal damage and cracking to tooth enamel caused by 1-ns laser ablation. (Right) Smooth hole with no thermal damage after drilling with a ultrashort pulse laser. 


\section{R\& D 100 Awards}

Each year R\&D M agazine selects the 100 most technologically significant products and processes submitted for consideration and honors them with an $R \& D 100$ Award. W inners are chosen by the editors of the magazine and a panel of 75 experts in a variety of disciplines. Corporations, government laboratories, private research institutes, and universities throughout the world vie for this "O scar" of applied research. The R\& D 100 judges look for products or processes that promise to change people's lives by significantly improving the environment, health care, or security.

\begin{tabular}{|c|c|c|c|}
\hline Year & Research Area & Institution & Technology Description \\
\hline 1998 & $\begin{array}{l}\text { High-performance } \\
\text { Electromagnetic } \\
\text { Roadway Mapping } \\
\text { and Evaluation System } \\
\text { (HERMES) }\end{array}$ & $\begin{array}{l}\text { LLNL, Federal } \\
\text { Highway } \\
\text { Administration }\end{array}$ & $\begin{array}{l}\text { A high-resolution, radar-based mobile inspection system for } \\
\text { detecting and mapping defects in bridge decks, highways, } \\
\text { tunnels and rapid transit systems, based on micropower } \\
\text { impulse radar. }\end{array}$ \\
\hline 1998 & Laser peening system & $\begin{array}{l}\text { LLNL, Metal } \\
\text { Improvement } \\
\text { Co. Inc. }\end{array}$ & $\begin{array}{l}\text { A high-average-power, pulsed laser-peening system that } \\
\text { instills deep compressive stress into metal components to } \\
\text { extend service lifetime. Applications include surface treatment } \\
\text { of aircraft fan blades, disks, and rotors; helicopter drive gears } \\
\text { and bearings; hip replacement joints in the medical industry; } \\
\text { oil drilling tools; and enhancing corrosion fatigue resistance } \\
\text { for DOE's nuclear waste storage containers. }\end{array}$ \\
\hline 1998 & $\begin{array}{l}\text { Optical dental imaging } \\
\text { system }\end{array}$ & $\begin{array}{l}\text { LLNL, } \\
\text { University of } \\
\text { Connecticut } \\
\text { Health Center }\end{array}$ & $\begin{array}{l}\text { A hand-held, noninvasive, high-resolution, optical dental } \\
\text { imaging system that can diagnose periodontal disease and } \\
\text { detect cavities. Applications include diagnosis of periodontal } \\
\text { diseases, detection of cavities, and evaluation of dental } \\
\text { restorations. }\end{array}$ \\
\hline 1998 & $\begin{array}{l}\text { Fiber optic infrared } \\
\text { temperature system }\end{array}$ & LLNL. & $\begin{array}{l}\text { A fast, accurate, high-resolution optical sensor that measures } \\
\text { temperature for medical and industrial applications such as } \\
\text { temperature-based laser controls for tissue welding of skin } \\
\text { grafts, laser-based surgery and nerve repair, and temperature } \\
\text { control of silicon wafer surfaces during the dry-etching process. }\end{array}$ \\
\hline 1997 & $\begin{array}{l}\text { Absolute } \\
\text { interferometer }\end{array}$ & LLNL & $\begin{array}{l}\text { A device that can measure the surface curvature of optics with } \\
\text { ultra-high accuracy-nearly } 1 / 1,000 \text { of a visible light } \\
\text { wavelength. This special capability greatly expands the } \\
\text { frontiers of the semiconductor and optical-manufacturing } \\
\text { industries. }\end{array}$ \\
\hline 1997 & $\begin{array}{l}\text { Ultra clean ion beam } \\
\text { sputter deposition } \\
\text { system }\end{array}$ & $\begin{array}{l}\text { LLNL, Veeco } \\
\text { Instruments, } \\
\text { Inc. }\end{array}$ & $\begin{array}{l}\text { A system that can produce defect-free reflective coatings on } \\
\text { masks used to transfer patterns onto silicon wafers or } \\
\text { microchips. The new system yields only two defects in } 100 \\
\mathrm{~cm}^{2} \text {, more than a } 300,000 \text {-fold improvement over the current } \\
\text { method. An enabling technology for extreme ultraviolet } \\
\text { (EUV) lithography to mass produce images or patterns on } \\
\text { integrated circuits. }\end{array}$ \\
\hline 1997 & $\begin{array}{l}\text { Femtosecond laser } \\
\text { materials processing }\end{array}$ & LLNL & $\begin{array}{l}\text { A high-repetition-fate, ultra-short pulse Ti-sapphire laser } \\
\text { system that can cut and drill materials with high precision and } \\
\text { high speed, with a minimal heat-affected zone. Applications } \\
\text { include chemical weapons dismantlement, machining of } \\
\text { electronic materials, drilling of high-precision holes, and hard- } \\
\text { tissue cutting of bones and teeth. }\end{array}$ \\
\hline
\end{tabular}




\begin{tabular}{|c|c|c|c|}
\hline 1997 & $\begin{array}{l}\text { Ultra-high gradient } \\
\text { insulator (UHGI) }\end{array}$ & $\begin{array}{l}\text { LLNL, } \\
\text { AlliedSignal } \\
\text { Federal } \\
\text { Manufacturing } \\
\text { \& Technology } \\
\text { Plant }\end{array}$ & $\begin{array}{l}\text { An ultra-high gradient device that can sustain four times higher } \\
\text { electrical voltage than of conventional insulators of similar } \\
\text { size. When applied to silicas or glass insulators, it can support } \\
175,000 \text { volts per centimeter, about five times the limit of } \\
\text { today's insulators. Applications include equipment size } \\
\text { reduction for accelerators, x-fay machines, and semiconductor } \\
\text { production tools. }\end{array}$ \\
\hline 1996 & $\begin{array}{l}\text { Ce:LiSAF, first } \\
\text { tunable ultraviolet } \\
\text { solid-state laser } \\
\text { product }\end{array}$ & $\begin{array}{l}\text { LLNL, VLOC } \\
\text { (formerly } \\
\text { Lightning } \\
\text { Optical } \\
\text { Corporation) }\end{array}$ & $\begin{array}{l}\text { A cerium-doped lithium-strontium-aluminum flouride optical } \\
\text { crystal used as laser gain media to generate tunable laser } \\
\text { output in the UV region. Applications include remote sensing } \\
\text { and optical communications between infantry units over short } \\
\text { distances. }\end{array}$ \\
\hline 1996 & $\begin{array}{l}\text { Six degrees of } \\
\text { freedom sensor }\end{array}$ & LLNL & $\begin{array}{l}\text { A small, noncontact optical sensor that can accurately monitor } \\
\text { its position in six degrees of freedom. This sensor can be used } \\
\text { to guide robotic machining tools to follow a pre-described } \\
\text { machining path and shorten the manufacturing process change- } \\
\text { out time. }\end{array}$ \\
\hline 1996 & $\begin{array}{l}\text { Ultrahigh-density } \\
\text { magnetic sensors }\end{array}$ & $\begin{array}{l}\text { LLNL, Read- } \\
\text { Rite } \\
\text { Corporation }\end{array}$ & $\begin{array}{l}\text { A critical component in magnetic storage devices such as } \\
\text { computer hard-disk drives. The new sensor using alternating } \\
\text { layers of thin magnetic and nonmagnetic materials offers greater } \\
\text { sensitivity and } 100 \text { times greater storage densities than current } \\
\text { commercial products, approaching the projected limit of } \\
\text { magnetic disk drive technology of } 100 \text { gigabit } 1 \text { in. }^{2}\left(6.4 \mathrm{~cm}^{2}\right) \text {. }\end{array}$ \\
\hline 1996 & Electronic dipstick & LLNL & $\begin{array}{l}\text { A low-power. low-cost }(<10 \$) \text { device that can measure the } \\
\text { fluid level in a container to better than } 0.1 \% \text { accuracy by } \\
\text { measuring the time it takes for an electrical impulse to reflect } \\
\text { from the liquid surface. Applications include measuring fluid } \\
\text { levels in cars, supertankers, and grain elevators. }\end{array}$ \\
\hline 1996 & $\begin{array}{l}\text { Lithography system } \\
\text { for flat-panel displays }\end{array}$ & LLNL & $\begin{array}{l}\text { A cost-effective laser interference lithography that can } \\
\text { precisely produce regular arrays of extremely small (less than } \\
100 \text { atoms wide) electron-generating field-emission tips. This } \\
\text { will advance the production of field-emission display flat } \\
\text { panels, which are thinner, brighter, larger, and have a wider } \\
\text { field of view than matrix liquid crystal displays. Applications } \\
\text { range from more efficient portable computers to virtual-reality } \\
\text { headsets and wall-hugging TV sets. }\end{array}$ \\
\hline 1995 & $\begin{array}{l}\text { High-average-power } \\
\text { solid-state laser with } \\
\text { high-pulse energy and } \\
\text { low beam divergence }\end{array}$ & LLNL & $\begin{array}{l}\text { A flashlamp-pumped Nd:glass zig-zag slab laser that can } \\
\text { deliver output power of } 150 \mathrm{~W} \text { ( } 25 \text {-to } 30 \text {-J per pulse at } 6 \mathrm{~Hz} \text { ) } \\
\text { with near-perfect beam quality and narrow spectral line width. } \\
\text { The performance of this system is } 10 \text { times that of any current } \\
\text { commercial product. Applications include advanced integrated } \\
\text { circuit production and coberent laser radar. }\end{array}$ \\
\hline 1995 & $\begin{array}{l}\text { All solid-state laser } \\
\text { with diode irradiance } \\
\text { conditioning }\end{array}$ & LLNL & $\begin{array}{l}\text { A new diode-pumped solid-state laser architecture that } \\
\text { integrates all key components (laser diode pump array, lens } \\
\text { duct optic, and laser gain medium) in a compact configuration. }\end{array}$ \\
\hline
\end{tabular}




\begin{tabular}{|c|c|c|c|}
\hline & & & $\begin{array}{l}\text { It offers a relatively inexpensive yet robust and reliable means } \\
\text { of generating coherent laser light for applications in medical } \\
\text { surgery, pollutant detection, and laser welding. }\end{array}$ \\
\hline 1995 & $\begin{array}{l}\text { Sealed-tube Electron } \\
\text { Beam Gun for } \\
\text { Material Processing }\end{array}$ & $\begin{array}{l}\text { LLNL, } \\
\text { American } \\
\text { International } \\
\text { Technologies }\end{array}$ & $\begin{array}{l}\text { A low-cost, durable, compact sealed-tube electron-beam gun } \\
\text { that can deliver } 2 \text { ma of } 65 \mathrm{kV} \text { electrons ( } 130 \mathrm{~W} \text { ) into the air. } \\
\text { The sealed tube uses a thin-film material as a vacuum window } \\
\text { that passes electrons of lower energy, eliminating the need for } \\
\text { costly high-vacuum systems. The major application is in } \\
\text { polymer curing. }\end{array}$ \\
\hline 1994 & $\begin{array}{l}\text { Multilayer dielectric } \\
\text { gratings }\end{array}$ & LLNL & $\begin{array}{l}\text { High-efficiency and high-damage-threshold gratings made of } \\
\text { mult-layer dielectric materials. The new gratings are attractive } \\
\text { for commercial high-power laser systems that employ gratings } \\
\text { for pulse compression. }\end{array}$ \\
\hline 1994 & $\begin{array}{l}\text { A process for rapid } \\
\text { growth of KDP } \\
\text { crystals }\end{array}$ & LLNL & $\begin{array}{l}\text { A method of growing high-quality potassium dihydrogen } \\
\text { phosphate (KDP) crystals about } 10 \text { to } 40 \text { times more quickly } \\
\text { than conventional methods, thus promising great savings in } \\
\text { laser technology and all other fields requiring high-quality } \\
\text { crystals. }\end{array}$ \\
\hline 1994 & $\begin{array}{l}\text { Ytterbium-doped } \\
\text { apartite laser crystals }\end{array}$ & $\begin{array}{l}\text { LLNL, } \\
\text { University of } \\
\text { Central Florida }\end{array}$ & $\begin{array}{l}\text { Ytterbium-doped apatite laser crystals, which have } 2.5 \text {-to- } 5 \\
\text { times more energy storage capacity than other laser crystals. } \\
\text { The apatites provide a means for attaining high-energy storage } \\
\text { with low loss in laser amplifiers and Q-switched oscillators. }\end{array}$ \\
\hline 1993 & $\begin{array}{l}\text { Modular high-power } \\
\text { laser diode array }\end{array}$ & LLNL & $\begin{array}{l}\text { A modular, high-power, laser-diode array packaged with } \\
\text { LLNL's cooling system for high-power operation that enables } \\
\text { lasers to operate at five times greater power than previously } \\
\text { possible and about seven times lower cost. }\end{array}$ \\
\hline 1993 & $\begin{array}{l}\text { Single-shot transient } \\
\text { digitizer }\end{array}$ & LLNL & $\begin{array}{l}\text { A system that can electronically record electrical signals as } \\
\text { short as } 30 \text { trillionths of a second. Applications include high- } \\
\text { speed physics, telecommunications, and testing of high-speed } \\
\text { digital computer ships. With low-cost, off-the-shelf components, } \\
\text { it is an inexpensive replacement for oscilloscopes. }\end{array}$ \\
\hline 1991 & $\begin{array}{l}\text { High-voltage, solid- } \\
\text { state switch for power } \\
\text { conditioning circuits }\end{array}$ & LLNL & $\begin{array}{l}\text { A solid-state switch assembly that combines the high } \\
\text { reliability of solid-state electronics with the high-voltage } \\
\text { standoff and high-current switching capabilities of thyratrons. } \\
\text { This switch assembly is more reliable and cost effective than } \\
\text { thyratrons. Applications include thyratron-replacements in the } \\
\text { power-conditioning circuitry for lasers, radars, accelerators, } \\
\text { and other devices. }\end{array}$ \\
\hline 1991 & $\begin{array}{l}\text { Cr:LiCAF and } \\
\text { Cf:LiSAF lasers }\end{array}$ & LLNL & $\begin{array}{l}\text { Crystals with versatile optical and physical properties that } \\
\text { could be used as gain media in tunable solid-sate lasers. These } \\
\text { crystalline lasers offer longer energy-storage lifetime, higher } \\
\text { efficiency, more flexibility in harmonic generation, and good } \\
\text { beam quality at high-average-power. They can be used in a } \\
\text { broad range of scientific, industrial, and defense applications. }\end{array}$ \\
\hline
\end{tabular}




\begin{tabular}{|l|l|l|l|}
\hline 1990 & $\begin{array}{l}\text { Ultra-thin diffractive } \\
\text { lens }\end{array}$ & $\begin{array}{l}\text { LLNL, } \\
\text { University of } \\
\text { California at } \\
\text { San Francisco }\end{array}$ & $\begin{array}{l}\text { An ultra-thin, flexible, diffractive lens that can image a broad } \\
\text { spectrum of wavelengths to a common focal point. It can } \\
\text { replace the artificial intraocular lens implants now used to } \\
\text { restore vision to cataract patients. This lens may be implanted } \\
\text { through a sutureless incision or placed directly on the cornea to } \\
\text { correct aphakia (absence of the natural lens), myopia } \\
\text { (nearsightedness), and hyperopia (farsightedness). }\end{array}$ \\
\hline 1990 & $\begin{array}{l}\text { Ultra-low-density } \\
\text { silica aerogel }\end{array}$ & LLNL & $\begin{array}{l}\text { An inorganic polymer foam in which the solid portion } \\
\text { occupies only 0.2\% of the total volume, yet no pore is larger } \\
\text { than a few hundred angstroms across. The foam is highly }\end{array}$ \\
\hline
\end{tabular}

\begin{tabular}{|l|l|l|l|}
\hline & & $\begin{array}{l}\text { compressible, elastic, and transparent with acoustic impedance } \\
\text { and thermal conductivity lowest of any known inorganic } \\
\text { material. The principal application of this aerogel is for } \\
\text { Cherenkov effect detection. }\end{array}$ \\
\hline 1989 & $\begin{array}{l}\text { Liquid crystal } \\
\text { polarizer }\end{array}$ & UR/LLE & $\begin{array}{l}\text { The concept for using liquid crystals in high-power lasers was } \\
\text { originated at LLE in 1979. }\end{array}$ \\
\hline
\end{tabular}

\begin{tabular}{|c|c|c|c|}
\hline 1989 & $\begin{array}{l}\text { Reflective } x \text {-ray mask } \\
\text { for lithography }\end{array}$ & LLNL & $\begin{array}{l}\text { A reflective } \mathrm{x} \text {-ray mask for lithography to eliminate the } \\
\text { problems of fragility and radiation sensitivity of conventional } \\
\mathrm{x} \text {-ray masks. It is an optically flat, multi-layer } \mathrm{x} \text {-ray mirror onto } \\
\text { which the metallization for an integrated circuit pattern is } \\
\text { deposited. It has applications for reproducing next-generation } \\
\text { high-density integrated circuit devices and allows the production } \\
\text { of } 400-\mathrm{Mbit} \text { DRAM devices on a } 1.5 \text { - } \mathrm{cm}^{2} \text { chip that usually } \\
\text { would hold } 4 \text {-Mbit devices. }\end{array}$ \\
\hline 1988 & $\begin{array}{l}\text { Composite polymer- } \\
\text { glass edge cladding }\end{array}$ & LLNL & $\begin{array}{l}\text { An optically absorbing edge cladding material applied to large } \\
\text { laser disks to reduce the undesired internal reflections in disks } \\
\text { that deplete the excited state populations and gains of optical } \\
\text { amplifiers. This method provides less index inhomogeneity } \\
\text { and stress-induced birefrengence near disk edges and costs a } \\
\text { fifth that of conventional fused-glass edge claddings. It can be } \\
\text { applied to all types of laser glass and crystals. }\end{array}$ \\
\hline 1988 & $\begin{array}{l}\text { Neutron penumbral- } \\
\text { aperture microscope }\end{array}$ & $\begin{array}{l}\text { LLNL, } \\
\text { University of } \\
\text { Melbourne }\end{array}$ & $\begin{array}{l}\text { A high-resolution, high-sensitivity neutron microscope that } \\
\text { uses a two-step coded aperture-imaging technique to produce } \\
\text { images of small } 14-\mathrm{MeV} \text { neutron sources. The device uses the } \\
\text { 14-MeV neutrons emitted by the deuterium-tritium fusion } \\
\text { reaction to present an image of the core of a laser-fusion target. }\end{array}$ \\
\hline 1988 & $\mathrm{X}$-ray laser cavity & LLNL & $\begin{array}{l}\text { A resonant optical feedback device that can increase output } \\
\text { power and efficiency of } x \text {-ray lasers by a factor of } 200 \text {, beam } \\
\text { divergence by an order of magnitude, and output brightness by } \\
\text { a factor of } 1600 \text {. It uses multi-layer mirrors and beamsplitters } \\
\text { to provide feedback and amplification to the gain medium. }\end{array}$ \\
\hline 1987 & Planar triode pulser & $\begin{array}{l}\text { LLNL, Grant } \\
\text { Applied } \\
\text { Physics, Inc. }\end{array}$ & $\begin{array}{l}\text { A high-power ultra-high-speed electrical pulser system that } \\
\text { can be used to drive fast-framing cameras for investigating } \\
\text { subnanosecond phenomena. The pulser is about } 100 \text { times } \\
\text { more powerful and } 10 \text { times faster than existing pulsers. The } \\
\text { principal application is in high-speed photography. }\end{array}$ \\
\hline
\end{tabular}




\begin{tabular}{|l|l|l|l|}
\hline 1987 & $\begin{array}{l}\text { Zone-plate coded } \\
\text { microscope }\end{array}$ & LLNL & $\begin{array}{l}\text { A broad-spectral-bandwidth microscope that uses a two-step } \\
\text { imaging technique to produce high-resolution ( } \mathrm{Z} \text { 1 } \mu \mathrm{m}) \mathrm{x} \text {-ray } \\
\text { images of small objects. The principal application is to provide } \\
\text { high-resolution, multi-spectral images of laser fusion } \\
\text { experiments and to image high-energy particle emissions, such } \\
\text { as neutron, proton, and alpha particles from radioactive sources. }\end{array}$ \\
\hline 1987 & $\begin{array}{l}\text { Highly dispersive } \\
\text { x-ray mirror }\end{array}$ & LLNL & $\begin{array}{l}\text { A generalized x-ray optical component that combines } \\
\text { lithography and multi-layer thin-film deposition to manipulate } \\
\text { x-fay beams and produce a three-dimensional x-ray diffraction } \\
\text { element. The mirror was developed for use in soft x-ray } \\
\text { cavities. Other applications include materials micro-analysis } \\
\text { and scanning x-ray spectroscopy of microbiological and solid- } \\
\text { state devices. }\end{array}$ \\
\hline 1987 & $\begin{array}{l}\text { Platinum-free } \\
\text { phosphate laser glass }\end{array}$ & $\begin{array}{l}\text { LLNL, Schott } \\
\text { Glass }\end{array}$ & $\begin{array}{l}\text { A special process that can reduce the Pt inclusion } \\
\text { concentrations in phosphate laser glass by a factor of 1000 to }\end{array}$ \\
\hline
\end{tabular}

\begin{tabular}{|l|l|l|l|}
\hline & & $\begin{array}{l}\text { Technologies, } \\
\text { Hoya Optics }\end{array}$ & $\begin{array}{l}\text { less than 0.1 per liter. The principal application is in high- } \\
\text { power laser systems as damage-resistant optical media. }\end{array}$ \\
\hline 1986 & $\begin{array}{l}\text { Particle beam fusion } \\
\text { accelerator II }\end{array}$ & SNL & $\begin{array}{l}\text { A device capable of igniting thermonuclear fuel in the lab and } \\
\text { the only inertial fusion approach with sufficient cost- and } \\
\text { energy-efficiency for commercial power production. }\end{array}$ \\
\hline 1986 & $\begin{array}{l}\text { Photonic high-speed } \\
\text { multichannel data } \\
\text { recorder }\end{array}$ & SNL & $\begin{array}{l}\text { A device that records multi-GHz, multihcannel photonic data, } \\
\text { facilitating the study of high-speed, single-shot, transient } \\
\text { phenomena over distances of several kilometers. }\end{array}$ \\
\hline
\end{tabular}

\begin{tabular}{|l|l|l|l|}
\hline & & $\begin{array}{l}\text { Technologies, } \\
\text { Hoya Optics }\end{array}$ & $\begin{array}{l}\text { less than 0.1 per liter. The principal application is in high- } \\
\text { power laser systems as damage-resistant optical media. }\end{array}$ \\
\hline 1986 & $\begin{array}{l}\text { Particle beam fusion } \\
\text { accelerator II }\end{array}$ & SNL & $\begin{array}{l}\text { A device capable of igniting thermonuclear fuel in the lab and } \\
\text { the only inertial fusion approach with sufficient cost- and } \\
\text { energy-efficiency for commercial power production. }\end{array}$ \\
\hline 1986 & $\begin{array}{l}\text { Photonic high-speed } \\
\text { multichannel data } \\
\text { recorder }\end{array}$ & SNL & $\begin{array}{l}\text { A device that records multi-GHz, multihcannel photonic data, } \\
\text { facilitating the study of high-speed, single-shot, transient } \\
\text { phenomena over distances of several kilometers. }\end{array}$ \\
\hline
\end{tabular}

\begin{tabular}{|l|l|l|l|}
\hline 1986 & $\begin{array}{l}\text { Precision engineering } \\
\text { research lathe }\end{array}$ & LLNL & $\begin{array}{l}\text { A research lathe that has an overall contouring accuracy of } 0.1 \\
\mu \mathrm{m} \text { in its } 100 \times 100 \text {-mm work zone. This small two-axis } \\
\text { computer-controlled turning machine can be used both for } \\
\text { production of optical quality contoured parts and for research } \\
\text { in precision metal cutting. Other applications include the } \\
\text { manufacture of infrared and visible-light metallic optics, } \\
\text { astronomical telescopes, and x-ray microscopes. }\end{array}$ \\
\hline 1986 & $\begin{array}{l}\text { Beamsplitter for low } \\
\text { energy x rays }\end{array}$ & LLNL & $\begin{array}{l}\text { An x-ray beamsplitter made of a thin multilayer film supported } \\
\text { by a thin } x \text {-ray-transparent silicon nitride membrane. It is an } \\
\text { x-ray analog of the optical two-way mirror, which divides an } \\
\text {-ray beam into a reflected and a transmitted beam, which } \\
\text { permits manipulation of } \mathrm{x} \text { rays. The principal application is the } \\
\text { development of } \mathrm{x} \text {-ray optical devices for micro-mechanics, } \\
\text { microbiology, and surface science. }\end{array}$ \\
\hline
\end{tabular}




\begin{tabular}{|l|l|l|l|}
\hline 1985 & $\begin{array}{l}\text { Time-resolved } \\
\text { imaging x-ray } \\
\text { spectrometer }\end{array}$ & LLNL & $\begin{array}{l}\text { A spectrometer using grazing incidence reflection from a large } \\
\text { ellipsoidal mirror to direct the x-ray emission image onto the } \\
\text { slit of an x-ray streak camera. It has a sensitivity three-to-four } \\
\text { orders of magnitude greater and a time resolution three orders } \\
\text { of magnitude higher than comparable instruments. The } \\
\text { principal application is in x-ray laser research. }\end{array}$ \\
\hline 1979 & $\begin{array}{l}\text { Nd-doped } \\
\text { fluorophosphate laser } \\
\text { glass }\end{array}$ & $\begin{array}{l}\text { LLNL, Owens } \\
\text { Illinois }\end{array}$ & $\begin{array}{l}\text { The glass to be used in the Nova Laser facility to determine the } \\
\text { feasibility of producing thermonuclear fusion energy from fuel } \\
\text { pellets implosively driven by laser light. The glass amplifies } \\
\text { 1052-nm laser light with little spatial distortion, providing } \\
\text { roughly twice the performance per unit cost in large laser } \\
\text { systems like Nova. }\end{array}$ \\
\hline 1978 & $\begin{array}{l}\text { Diamond machining } \\
\text { process }\end{array}$ & $\begin{array}{l}\text { LLNL, Union } \\
\text { Carbide }\end{array}$ & $\begin{array}{l}\text { Process that allows direct fabrication of optical components } \\
\text { using a single-point diamond tool and a specially constructed } \\
\text { machine tool, which produces a variety of optical components, } \\
\text { such as aspherical surfaces, conical surfaces, and flats with } \\
\text { discontinuous surfaces, in a shorter time and at less expense } \\
\text { than conventional processes. Applications include the } \\
\text { manufacture of reflective metal optics for high-energy lasers } \\
\text { and optical components for infrared and x-ray imaging. }\end{array}$ \\
\hline
\end{tabular}

\section{Conclusions}

There can be little doubt that the community of scientists and engineers working on inertial fusion around the world has provided broad technology spin-offs in a variety of fields and industries. This has been driven by the extremely challenging technical problems that the community faces and the technical strengths of individual inertial fusion researchers. We are confident that an investment to develop inertial fusion energy will reap similar benefits in the future.

For further information or to gain contact with individuals knowledgeable about the spin-offs cited, please contact $\mathrm{H}$ oward Powell at Lawrence Livermore $\mathrm{N}$ ational Laboratory (e-mail: powell4@llnl.gov or phone: 925-422-6149. 